\title{
THE PRESIDENT'S EXCLUSIVE FOREIGN AFFAIRS POWERS OVER FOREIGN AID: PART II $\dagger$
}

\author{
DoN WAllace, JR.*
}

CONTENTS

Part II

THE APPLICATION OF CONSTITUTIONAL STANDARDS TO FOREIGN AID

Factors Weighed in Striking the Balance Reflected in

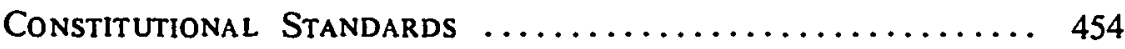

External Necessity; Executive Efficiency

and Expertise ............................. 455

Individual Rights, Democratic Control, and

Congressional Expertise ....................... 464

The foreign aid Program $\ldots \ldots \ldots \ldots \ldots \ldots \ldots \ldots \ldots \ldots . \ldots . \ldots . \ldots . \ldots$

The Application of the Standards $\ldots \ldots \ldots \ldots \ldots \ldots \ldots \ldots .471$

Foreign Aid Within the Independent Powers

of the President ............................. 47I

Exclusive Powers of the President ................. 472

a) Directions to the President .................. 472

b) Congressional and Committee Vetoes ............. 473

c) Executive Secrecy ....................... 474

d) Pressure on the Traditional Core Area ............ 476

e) Pressure on the Traditional and New Core Areas ...... 477

i) Pressure and Restrictions on the New Core Area ....... 479

g) Administrative Detail ................... 480

h) Financial Terms, Operating Procedures, and
Procurement Provisions ................... 481

i) Categories, Line Items, and Other Niceties ........ 482

† Part I appeared in the April 1970 issue of the Duke Law Journal.

* Associate Professor of Law and Director, Institute of International and Foreign Trade Law, Georgetown University Law Center. B.A. 1953, Yale College; LL.B. 1957, Harvard University. Formerly the author was Deputy Assistant General Counsel, Agency for International Development, United States Department of State. 
The Manner of application of Constitutional Standards

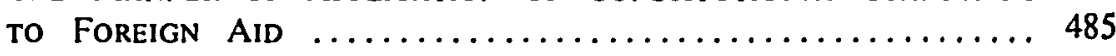

Judicial Definition ...................... 485

Executive Initiative and Congressional Restraint ......... 489

\section{THE APPLICATION OF CONSTITUTIONAL STANDARDS TO FOREIGN AID}

Before examining how the constitutional standards discussed in Part I might be applied to foreign aid, it is necessary to consider briefly first, the reasons for the constitutional standards that have developed and, second, the foreign aid program itself.

\section{Factors Weighed in Striking the Balance Reflected in CONSTITUTIONAL STANDARDS}

Most of the reasons adduced by the courts, the executive, the Congress, and the writers for striking the balance where they have with respect to the President's foreign affairs powers do not go expressly to his exclusive powers, but rather to explain why he has independent powers in foreign affairs in contrast to the delegated powers he must largely rely on in domestic affairs. ${ }^{217}$ However, it can be assumed that the reasons enunciated to support the executive's independent powers, that is, the ability to act in the absence of congressional action, may also become reasons to support its exclusive powers, permitting the executive to act alone, free of congressional control. ${ }^{218}$

217. There is clearly a "domestic" core of government decisions and relevant powers, and another separate "foreign" core. United States v. Curtiss-Wright Export Corp., 299 U.S. 304, 319 (1936) ("Federal power over external affairs [is] in origin and essential character different from that over internal affairs"); $c f$. Youngstown Sheet \& Tube Co. v. Sawyer, 343 U.S. 579, 645 (1952) (Jackson, J., concurring, distinguishes between national force "turned against the outside world" from that "turned inward"). But, nevertheless, there is a recognizable and "growing comingling of foreign and domestic affairs." Walker, Our Foreign Affairs Machinery: Time for an Overhaul, 47 Foreign Affalrs 309, 310 (1969). For example, Mr. Walker notes that there are 56 United States government agencies, many of them "domestic," with representatives in one or more foreign countries. Id.

218. One school would put all executive power-and the term may beg the question-in the President unless the Constitution clearly provides otherwise. See note 171 supra (Thomas Jefferson's statement that the transaction of all foreign affairs is Executive unlcss the Constitution specifies otherwise). This was the position of Alexander Hamilton in his debate 


\section{External Necessity: Executive Efficiency and Expertise}

John Locke enunciated the basic difference between the international order of nation-states and the domestic order of a nation. state: "[F]or though in a commonwealth the members of it are . . governed by the laws of the society, yet in reference to the rest of mankind they make one body, which is . . . still in the state of nature . . . "219 Charles de Visscher has suggested the implications of this "instability [of relations], exceptional in the internal order . . . [: it] is the more or less general condition of the international order, dominated and constantly troubled . . . by the fact or of force." ${ }^{220}$ With international law and organization largely insufficient to ensure the security of nation-states, their right to secure their own essential interests becomes the condition of minimum world order. ${ }^{221}$

with James Madison: "The general doctrine of our Constitution then is, that the executive power of the nation is vested in the President; subject only to the exceptions and qualifications, which are expressed in the instrument." E. Corwin, The President's Control of Foreign Relations 11-12 (1917) [hereinafter citcd as CoRwin-Foreign Relations]; Senator Spooner, id. at 169; $c f$. Banco Nacional de Cuba v. Farr, 383 F.2d 166, 182 (2d Cir. 1967); Sayre, The Constitutionality of the Trade Agreements Act, 39 Colum. L. Rev. 751, 753 (1939). Theodore Roosevelt took a similar position with respect to all matters, foreign and domestic: "[T] the Constitution or imposed by the Congress under its Constitutional powers. My view was that every executive officer . . . was a steward of the people. . . . My belief was that it was not only his right but his duty to do anything that the needs of the Nation demanded unless such action was forbidden by the Constitution or by the laws. . . I did not usurp power, but 1 did greatly broaden the use of executive power." T. ROOSEVELT, AN AUTOB1OGRAPHY 357 (1913). A discussion of the judicial power in Karsas v. Colorado, 206 U.S. 46 (1907), similarly begs the question:

[United States Constitution art. 1 treatment] of legislative powers, does not make a general grant of legislative powers, . . . on the other hand . . . [a]rticle (111) . . . [which] reads that "the judicial power shall be vested . . ." [grants] the entire judicial power of the Nation . . . . There may be, of course, limitations in that grant of power, but if there are any, they must be expressed; for otherwise the general grant would vest in the courts all the judicial power which the new nation was capable of exercising. . . ." 206 U.S. at $81-83$.

219. J. Locke, Second Treatise on Civil Government, \& 145 (1690). See also id. $\S \S 146,148$. A domestic insurrection may present problems in some ways comparable to those of the external order.

220. C. De Visscher, Theory and Reality in Public International Law 135 (1957).

221. McDougal \& Lans, Treaties and Congressional-Executive or Presidential Agreements: Interchangeable Instruments of National Policy: I, 54 Y ALE L.J. 181, 185-86 (1945) [hereinafter cited as McDougal \& Lans]. Compare the Supreme Court's reference to the foreign affairs powers as "necessary concomitants of nationality." United States v. Curtiss-Wright Export Corp., 299 U.S. 304,318 (1936). 
Presumably President Kennedy had this state of affairs in mind when speaking during the Cuban missile crisis:

[T] He United States has the means as a sovereign power to defend itself . . . . We would hope to exercise [that power] . . . in a way consistent with our treaty obligations, including the United Nations Charter. But we, of course, keep to ourselves and hold to ourselves under the United States Constitution and under the laws of international law, the right to defend our security. On our own, if necessary ... [we will act] to protect our survival or integrity or other vital interests. 222

Our survival and security, being of paramount importance to us, have been entrusted to the governmental institution best equipped to assure them. As a nation we have concluded that the institutional capacities ${ }^{223}$ of the executive branch, or at least relative to those of the Congress, are superior for the task. ${ }^{22}$ An examination of these superior executive capacities and the corollary congressional deficiencies is therefore appropriate.

The executive, as an institution, has a greater involvement in, and sense of, world power relations and dynamics than does the Congress. ${ }^{225}$ Professor Corwin, not an especial friend of Presidential power, notes that "the President occupies a superior position from which to descry the approach of crisis, especially crisis in the international field." ${ }^{226}$ The executive has greater knowledge of other nations' interests and policies and their view of our policies and

222. Public Papers of the President: John F. Kennedy, 1962 at 836 (1963) (press conference).

223. Thus, it is the capacities of Congress as an institution, rather than its individual members, with which we are concerned. Compare the reference to "the competency of dissimilar institutions [the executive and the courts] to make and implement particular kinds of decision in the area of international relations." Banco Nacional de Cuba v. Sabbatino, 376 U.S. 398, 404 (1964).

224. Certainly the executive has deficiencies. It has been suggested that the bureaucracy suffers from two forms of inertia: (1) its rigidity, as suggested by Henry Kissinger in the N.Y. Times, Dec. 7, 1968, at 57, col. 3, and (2) its difficult-to-control momentum, suggested inter alla by R. Neustadt, Presidential Power: The Politics of Leadership (1960). Indeed, a "bureaucratic model" of foreign policy formulation has been proposed. Hilsman, The Foreign-Policy Consensus; 613 CONflict Resolution 361 (1959); RAND CORPORATION RePort, THe Cuban Missile Crisis 3919 (1968).

Senator Fulbright has also suggested that too many of our top foreign policy people are not sufficiently professional. Fulbright, American Foreign Policy in the 20th Century Under an 18 th Century Constitution. 47 CORNeLL L.Q. I (1961) Thereinafter cited as Fulbright, 20th Centuryl.

225. Notwithstanding the fact that the Congress has delegated much authority to the executive, suggesting the practical necessity for executivc action in domestic affairs as well, it remains true that the dynamics of domestic affairs are different from those of international ones. Cf. note 219 supra and accompanying text.

226. E. Corwin, The President: Office and POWers, 1787-1957 at Ch. VII n.76 (1957) [hereinafter cited as CoRWIN-PRESIDENT]. 
actions. ${ }^{227}$ Senator William Fulbright has acknowledged the "specialized skills"'228 of the executive, and it is clear that the executive has far greater expertise in diplomacy, skill in the administration of aid, ${ }^{220}$ experience in communicating across cultures, and receptivity to the sensibilities of other nations and cultures. A possibly greater virtue of the executive is its ability to apply the "force of society" to the national security and related interests. As enunciated by Locke:

Though . . . the executive and federative power (the power of war and peace, leagues, and alliances, and all the transactions with all persons and communities without the commonwealth) of every community be really distinct in themselves, yet they are hardly to be separated and placed at the same time in the hands of distinct persons. For both of them [require] . . . the force of society for their exercise. . . .200

It has often been noted by the Supreme Court that in foreign affairs the nation must speak with "one voice."?31 That voice will usually be the President's because, as "the political focus of high policy and politics' "232 and the "highest point of governmental leadership,"'233 he will be closest to the international order.

227. For example, the concerned members of the executive may have greater awarness of foreign reliance on our commitments than will most Congressmen. Note, Presidential Amendment and Termination of Treaties: The Case of the Warsaw Convention, 34 U. CH1. L. REV. 580, 602 (1967).

228. Hearings on Separation of Powers Before the Subcomm. on Separation of Powers of the Senate Comm. on the Judiciary, 90th Cong., Ist Sess. 43 (1967) [hereinafter cited as Hearings, Separation of Powers].

229. The administration of foreign aid may well entail far greater involvement in the affairs of a country than does the more traditional diplomacy. See generally A. KRASSOWSKI, THE AID RELATIONSHIP (1968).

230. J. Locke, Second TREATISE ON Civil Government §§ 145-46, 148 (1690). Compare the difficulties experienced by the Confederation, which had no executive. 1t is probably significant that while "decentralization" to local institutions has been suggested as a cure for many of our domestic ills, no sort of "decentralization" has been suggested for the conduct of the core area of our foreign affairs. Rather, it has bcen suggested that in the most important areas of foreign affairs, any considerable measure of increased decentralization, even within the executive, may not be feasible. Hearings on Administration of National Security Before the Senate Subcomm. on National Security Staffing and Operations, 88th Cong., 2d Sess., pt. 1, at 10 (1965) [hereinafter cited as Hearings, National Security]. Recently efforts have been made to further coordinate the different foreign programs within the executive. Compare also the Supreme Court's exclusion of the states from certain areas of foreign affairs. E.g., Zschernig v. Miller, 339 U.S. 429 (1968).

231. E.g., Banco Nacional de Cuba v. Sabbatino, 376 U.S. 398 (1964); Baker v. Carr, 369 U.S. 186 (1962). "Such questions [touching foreign relations] uniquely demand single-voiced statements of the Government's views." 369 U.S. at 211.

232. W. Gellhorn \& C. BySE, Administrative LAW 203 n.13 (4th ed. 1960) [hereinafter cited as GELLHORN \& BYSE]. 
The President is in the best position to escape special interests, apply a unified policy, and integrate our various foreign policies and programs. ${ }^{234}$ By contrast, "under the legislative process, individual proposals may be and frequently are considered severally, far from the context of total foreign policy . . . . This decentralized and disjointed process is not conducive to the creation of any grand pattern or even to the consideration of the costs and the alternatives." ${ }_{236}$ In recognizing the superior knowledge and information of the exccutive, the Supreme Court has said, "[the President], not Congress, has the better opportunity of knowing the conditions which prevail in foreign countries .... He has his confidential sources of information. He has his agents in the form of diplomatic, consular and other officials. Secrecy in respect of information gathered by them may be highly necessary . ..." 236

The Senate Foreign Relations Committee stated in a report of February 15, 1816 that "[The President] manages our concerns with foreign nations and must necessarily be most competent to determine when, how, and upon what subjects negotiation may be urged with the greatest prospect of success. " ${ }^{237}$ The superior capacity of the executive in the negotiating of agreements was recognized in The Federalist No. 75: "qualities . . . indispensable in the management of foreign negotiations point out the executive as the most fit agent in those transactions." 238 The speed, secrecy, and flexibility of the executive-qualities often cited as necessary for the effective conduct of certain aspects of foreign affairs-frequently have been noted. ${ }^{239}$

233. Steelman and Kreager. The Executive Office as Administrative Coordinator. 21 Law \& CONTEMP. PrOB. 688, 709 (1956).

234. Senator Jackson has observed that

[o]nly the President stands above all departments and agencies and only he and his principal lieutenants can see the problems of a country or a region in the perspeetive of national policy as a whole. . . . The higher the issues are pulled for decision, the greater the chance that the pressure of special interests can be resisted, that irrelevant consideration will be screened out, and that material considerations will be properly weighed. Hearings. National Security 10.

235. Thorp, Sirings on Economic Aid, 44 Yale Review 202, 213 (1954).

236. United States v. $\dot{C}$ urtiss-Wright Export Corp., 299 U.S. 304, 320 (1936); cf. Zemel v. Rusk, 381 U.S. 1, 17 (1963); Chicago \& S.A.L. v. Waterman, 333 U.S. 103, 111 (1948) ("The President, both as Commander-in-Chief and as the Nation's organ for foreign affairs, has available intelligence services whose reports are not and ought not to be published to the world.").

237. United States v. Curtiss-Wright Export Corp., 299 U.S. 304, 319 (1936).

238. The Federalist No. 75 , at 467 (H. Lodge ed. 1888) (A. Hamilion).

239. See, e.g.. McDougal \& Lans 248-52, 261-89. 
Vis-à-vis the executive, the deficiencies of the Congress are fairly obvious. "[T] he Congress, whose members are elected largely on the basis of local issues, possesses a greater degree of information and competence in domestic matters than it does in the foreign field." ${ }^{240}$ The Chairman of the Senate Foreign Relations Committee has referred to the Congress as "a decentralized, independent minded and largely parochial minded body of legislators." ${ }^{241}$ Its constituents, of whose interests it is ever conscious, are essentially interested in domestic issues. However, it is ironic that in domestic affairs, where executive agencies exercise powers delegated by Congress, they often have strong independent support among such constituents ${ }^{242}$ which they can mobilize against the Congress and, thus, sometimes further the constituents' interests. Neither the State Department nor AlD have such support to pit against Congress: "Foreign aid, after all, is ... a program without a constituency, excepting the poor, hungry and politically threatened in foreign lands-none of whom can cast a ballot [in the United States]. " ${ }^{243}$

The unwieldiness of the Congress is another deficiency, because "[i]t is nothing short of fantastic to assume that the control of foreign relations could in fact be shared equally by .97 men." 244 In fact, the Congress functions largely through committees and subcommittees, bodies which have their own deficiencies. ${ }^{245}$

It has been acknowledged that the management of foreign affairs requires specialist skills, often based on experience, as well as full time attention. Few members of Congress have the necessary expertise or information. Although congressional foreign travel has increased, ${ }^{246}$ it involves a relatively small number of men and is, of course, very part-time at best. Moreover, because of the demands of domestic issues, Congressmen do not have the time required to

240. Mathews, The Constitutional Power of the President to Conclude International Agreements, 64 YALE L.J. 345, 374 (1955) [hereinafter cited as Mathews].

241. Fulbright, 20th Century 6.

242. M. Jewell, Senatorial Politics. and Foreign Policy 136 (1962).

243. TiME, July 26, 1968, at 25 .

244. McDougal \& Lans. The 97 in the quotation refers to the President and the 96 members of the Senate in 1945.

245. See notes 251-57 infra and accompanying text.

246. ZinN, EXtent of the Control of the Executive by the Congress of the UNited States, House Committee on Government Operations, 87th Cong., 2d Sess. 26 n.29 (1962). 
master the many complicated issues of foreign affairs. ${ }^{247}$ Although members of the executive are also busy, in many cases their time is devoted to the specialty of foreign affairs. Senator Fulbright has also acknowledged this fact: "The Senate as a practical matter is very poorly equipped to deal with day-to-day policy-making or to try to outguess the President in this field." 248 Furthermore, there is little incentive for any significant number of Congressmen to acquire expertise in foreign affairs to a level necessitated by the realities of the external order. It is difficult to make much public splash in the Congress over foreign policy-at least through affirmative efforts. The negative criticisms of Senator Keating over the Cuban missiles, or the late Senator Joseph McCarthy over a range of issues, are atypical experiences. As foreign affairs are in fact at the present time largely an executive matter, the prospect of high executive office might normally be an incentive to the acquisition of foreign affairs expertise. However, neither the Senate nor the House are common routes to such office. ${ }^{2+9}$

The situation is of course quite different with respect to domestic matters; the Congress reflects and represents an electorate which largely constitutes the dynamics of the domestic order. But, as indicated, Congress knows little of, and is not really party to, the dynamics of the international order. The principal consequence of this would seem to be that whereas in domestic affairs it may not be inappropriate for the Congress to involve itself in rather specific detail, in foreign affairs the Congress has the capacity to concern itself only with generalities.

Congress is sometimes preferred to the executive as a repository of power because it is said to be more democratic. ${ }^{250}$ Yet, when it functions through committees and subcommittees ${ }^{251}$-certainly' with

247. Hilsman, Congressional-Executive Relations and the Foreign Policy Consensus, $52 \mathrm{AM}$. Pol. SCI. REv. 725, 727 (1958) [hereinafter cited as Hilsman, Congressional-Executive Relations].

248. N.Y. Times, May 10, 1959, §6 (Magazine), at 73-74. To say that Congressmen are "becoming mired in trivia" seems an exaggeration. Newman \& Keaton, Congress and the Faithful Execution of Laws-Should Legislators Supervise Administrators? 4] CALIF. L. REv, 565,593 (1953). But certainly most are generalists, GELLHORN \& BYSE 170; for reasons already suggested few certainly are foreign affairs speeialists. It is therefore probably fair to say that these factors "conspire to make it impossible for the Congressmen to take a regular part in the actual formulation of policy with anything approaching consistent responsibility to Executive interests." Hilsman, Congressional-Executive Relations 739.

249. Compare Senator Fulbright's reference to the Senate as a "disintergrated ministry." Fulbright, 20th Century 6.

250. See, e.g. THE Federalist No. 48, at 333-34 (J. Cooke ed. 1961) (J. Madison).

251. See notes $271-73$ infra and accompanying text. 
respect to foreign affairs-it may lack even that attribute. Moreover, the committee system may not lend itself to the unified view necessary for foreign affairs. An initial problem is that the composition of committees is unrepresentative. "A committee cannot represent any more than a particular segment of the country, depending upon the extent of its membership and the areas they are from and the extent of their jurisdiction. It does not represent the cross-section of public opinion and of interest that the Congress as a whole represents." 252 Moreover, as shall be seen, the chairmen, and occasionally other individual members, have a great influence on the work of committees and subcommittees. ${ }^{253}$ And the method of selection of such committee chairmen is not always very democratic, ${ }^{254}$ nor relevant to the particular problems the committee considers. For example, the method used to select the Chairman of the House Appropriations Subcommittee dealing with foreign aid would seem to have little relevance to the usual modalities of foreign policy formulation. Indeed, it has been suggested that Congressman Passman was selected by the Chairman of the relevant House Appropriations Committee because of his enmity to foreign aid. ${ }^{255}$ It is also clear that committees respond to special interests and pressure groups. Moreover, the absence, except as to trade, of a "solid array" of pressure groups with respect to foreign affairs, so common in domestic affairs, ${ }^{256}$ removes another possibly democratic discipline on the committees. A unified foreign policy is not furthered by the fact that committees often function semiautonomously of each other. Speaking of the House, one author has written: "Displayed is a picture of the uncoordinated control of interrelated foreigh policy matters by a host of little governments upon which the House [has] devolved great powers.' ${ }^{257}$

A final deficiency of the Congress arises from the nature of much present day foreign policy formulation, certainly of the kind that relates to the core area. George Ball has characterized it as a "surfeit of pragmatism. " 258 No doubt there are many explanations for this

252. Hearings, Separation of Powers 125 (Deputy Director Hughes, Bureau of the Budget); id. at 248 (Professor Bickel).

253. See notes $272-73$ infra and note 340 infra and aecompanying text.

254. See generally R. Dahl, Congress and Foreign Policy (1964).

255. D. Morrow, Congress and ICA: A Study in Legislative Control of ADMinistrative DeCisions, 1953-60 at 48 (1961).

256. Hilsman, Congressional-Executive Relations 727.

257. H. Carroll, The House of Representatives and Foreign Affairs 89 (1958).

258. G. Bal.l., The Discipline of Power 27 \& 343 (1968). See generally Hilsman, supra note 224. 
state of affairs. One reason would seem to be the sheer number of problems calling for decisions, with time at the top for only the really urgent ones. ${ }^{259}$ At the same time, given the rapidity of change in the world, the conflicting factual reports, the frequent urgency of decision, and other factors, it is clear that many decisions will always represent extremely fine calculations, often founded on one's deepest instinct and judgment and not lending themselves to systematic articulation or defense. ${ }^{260}$ No doubt the workings of the bureaucracy contribute to this approach. In any case it is not clear that the deliberative processes of Congress, which may be required to quickly revise legislative restrictions, ${ }^{261}$ can readily be more closely related to this pragmatic mode of operation.

In light of all these factors, many of which have long been apparent, it is not surprising that although the Constitution is not as explicit as it might be, the Founding Fathers fairly clearly intended the executive to have principal responsibility for foreign affairs, ${ }^{262}$ much as in other countries. ${ }^{263}$ Certainly this.was the position of such theorists as Locke, Montesquieu, and Blackstone, by whom the Founders were greatly influenced. ${ }^{264}$ Quincy Wright has noted that the

259. Hilsman, supra note 258, at 372.

260. Hearings, National Security 86.

261. See notes 268-73 infra and accompanying text.

262. See Corwin-Foreign Relations 166. See also C. Berdahl, War Powers of the EXECUtive IN the UNITED States (1920) thereinafter cited as Berdahl]; Q. WRIGHT, ThB Control of American Foreign Relations (1922) thereinafter cited as Wright-ForeigN RELATIONS].

263. Probably reflecting the historic fact that the executive in most eountries has had responsibility for foreign affairs, international law accords it substantial authority to conclude agreements. Legal Status of East Greenland, P.C.I.J., serv. A/B, No. 53 (1933); RESTATEMENT SECOND OF ForEign ReLATIONS LAW $§ 123$ (1965) [hereinafter cited as Restatement].

264. Debates at the Constitutional Convention and the state ratifying conventions contain little on the exclusive powers of the President. See generally Corwin-President Ch. V; Corwin-Foreign Relations; Wright, Foreign Relations; Mathews; McDougal \& Lans. The prior colonial and Confederation periods shed little light. During the former the royal government in London was principally responsible for foreign affairs. See United States v. Curtiss-Wright Export Corp., 299 U.S. 304, 316 (1936). See also J. BURns, Controverstes Between Royal Governors and Their Assembles in the Northern American Colonibs (1923); O. Dickerson, American Colonial Government: 1696-1765 (1939); H. Egerton, Origin and Growth of Greater Britain (1924); E. Greene, The Provincial Governori in THE ENGLish Colonies of North AMerica (1966). The local governors did in fact have some responsibility for relations with Indians and other colonies, and the local assemblies on occasions used the power of the purse to influenee the governor. BURNS, supra, at 416; GRRENE, supra, at 192-93. During the Confederation period there was no executive. ArTicles of Confederation, art. 1X, cl. 1. Indeed the weakness of the Confederation in foreign affairs because of the lack of an executive was one of the principal causes for the calling of the Constitutional Convention in 1787. McDougal \& Lans 221 \& n.34. 
treaty power and the power to declare war were the only divergences from traditional principles in this regard. ${ }^{265}$ It has been shown in Part I how practice soon conformed the operation of the treaty power-and probably the power to declare war as well-to more traditional modes.

While the executive's capacity to respond with speed and dispatch to crises may be at the root of its power, ${ }^{266}$ it has been observed that its specialized capacities for negotiation and the day-to-day conduct of foreign business, as well as its knowledge and familiarity with the dynamics of world problems, have also brought a broad range of affairs within its exclusive powers. The President now occupies the center of the Nation's foreign affairs, a fact made inevitable by the exercise of his initiative. To give the Congress a greater role at the center is to run the risk of introducing a second main focus, further diluting an executive machinery which already may have too many foci. Thus today, according to Senator Fulbright, "the only source of effective foreign policy under our system is presidential power.' '267

Congressional control by statute merely serves to underline and to magnify these deficiencies. Statutes lacking the flexibility required in the day-to-day conduct of foreign affairs may introduce rigidities and constraints. Locke deemed them inappropriate: "[The federative power (the executive power over foreign affairs)] is much less capable to be directed by antecedent, standing, positive laws than the [normal] executive [power] and so must necessarily be left to the prudence and wisdom [of the executive]." "268 Furthermore, legislation may well dictate a result inconsistent with the necessities imposed upon the Nation by the international order. That any legislative solution is ever exactly correct is unlikely. Finally, the situation can change quickly from that in existence at the time the legislation was passed, and it may prove difficult or impossible to repeal or modify the legislation to

265. See note 111 supra and accompanying text.

266. "The degree of crisis and amount of time available for decisions have customarily determined the scope of the president's substantive powers in the.field of foreign affairs. . .." Mathews 375; cf. Youngstown Sheet \& Tube Co. v. Sawyer, 343 U.S. 579, $601-02$ (1952).

267. Fulbright, 20 th Century 2.

268. J. Locke, Second Treatise on Civil Government § 144 (MacMillan ed. 1956). Lord Bryce wrote that "foreign affairs . . cannot be brought within the scope of statutes . . . [theyl cannot be provided for beforehand by laws general in application, but minutely particular in wording." I L. Bryce, The American Commonwealth 224 (3d ed. 1906). See also G. KEnNAN, MEMOIRs: 1925-50 at 409 (1967). We will see that the degree of rigidity can vary and that some of the restrictions on the foreign aid program may, by their terms, be waivable or subject to liberal construction. 
accommodate the new situation. For example, section $620(j)$ of the Foreign Assistance Act [FAA] as amended in 1967,260 which barred aid to Indonesia, may have delayed resumption of foreign aid to that country longer than was wise. ${ }^{270}$

The peculiar inadequacies of the committee system for purposes of foreign affairs have already been reviewed.$^{271}$ Most legislation, including restrictions on foreign aid, in fact originates in committee, and much remains unchanged on the floor out of deference to the committee, its chairman, or other sponsors of the legislation with the expectation that other proposed legislation will be likewise respected. ${ }^{272}$ The influence of single individuals, not always known for their particular wisdom in foreign affairs, can be disproportionate under such a system. Senator McCarran's and Representative Walters' influence on the immigration legislation bearing their name is one example. And, George Ball has suggested that some of the legislative restrictions on the aid program are merely "Mr. Passman's views become law." 273

Above all, the inappropriateness of legislative restrictions upon the President in foreign, as distinguished from domestic, affairs becomes apparent when one recollects: (1) Locke's distinction between a domestic society governed, and governable, by laws and an international realm in a "state of nature"'; and (2) Congress" responsiveness to the dynamics of domestic politics, as opposed to its only tangential familiarity with foreign affairs.

\section{Individual Rights, Democratic Control, and Congressional Expertise}

Where individuals' rights are involved, the courts have frequently recognized Congress' power to apply its expertise. ${ }^{274}$ Where such

\footnotetext{
269. 22 U.S.C. $\S \S 2151-2407$ (1964) [hereinafter cited as FAA].

270. FAA § 620(j) was in fact waivable by the President.

271. See notes $251-57$ supra and accompanying text.

272. D. MoRrow. supra note 255.

273. G. BALL, supra note 258 , at 36 .

274. E.g., Banco Nacional de Cuba v. Farr, 383 F.2d 166 (2d Cir. 1967) (expropriation; Sabbatino Amendment); Zemel v. Rusk, 381 U.S. 1 (1965) (passports); Valentine v. United States, 299 U.S. 5 (1936) (extradition power based on treaty or legislation); La Abra Silver Mining Co. v. United States, 175 U.S. 423 (1899) (claims); United States v. Eaton, 144 U.S. 677 (1892). See Youngstown Sheet \& Tube Co. v. Sawyer, 343 U.S. 579 (1952), arising out of the Korean War; World War II cases such as Duncan v. Kabanamoku, 327 U.S. 304 (1946); In re Yamashita, 327 U.S. 1 (1946); Korematsu v. United States, 323 U.S. 214 (1944); and Hirabayashi v. United States, 320 U.S. 81 (1943); Civil War cases such as Ex parte Milligan, 71 U.S. (4 Wall.) 2 (1866) and Ex parte Merryman, 17 F. Cas. 144 (No. 9,487) (C.C.D. Mid. 1861).
} 
rights are not so immediately involved, or the factors discussed above are dcemed to outweigh any possible impact on individual rights, Congress may lack "power." This is the case with respect to the core area, where in the vast majority of cases government activity takes place at the level of the public order, involving the relationship of the executive and Congress, rather than the private order of private rights. This distinction between the problems of the public order and the private order has been recognized by the courts. Thus, in Marbury $v$. Madison, ${ }^{275}$ it was noted that "[the] president is invested with certain important political powers ... . They respect the nation, not individual rights . . . The application of this remark will be perceived by adverting to the act of congress for establishing the department of foreign affairs." 276 Judge Fahy in Shachtman $v$. Dulles ${ }^{277}$ recognized the distinction when he remarked that "the right of a particular individual to travel [was] involved and not a question of foreign affairs on a political level." 278

The non-application of the doctrine of separation of powers to the core area follows from the purpose of that doctrine-the protection of individual liberties. As enunciated by Justice Brandeis, "[ $t]$ he doctrine of the separation of powers was adopted by the Convention of 1787 not to promote efficiency but to preclude the exercise of arbitrary power. The purpose was, not to avoid friction, but, by

But of. Derecktor v. United States, 128 F. Supp. 136, appeal dismissed 350 U.S. 802 (1955) (foreign policy over contract rights); United States v. Caltex (Philippines) Inc., 344 U.S. 149 (1952); Ex parte Quirin, 317 U.S. 1 (1942) (Commander-in-Chief powers over rights of enemy belligerent). See also Leigh \& Atkeson, Due Process in the Emerging Foreign Relations Law of the United States, 21 Bus. LAw. 853, 22 Bus. LAw. 3 (1966); Miller, The American Corporation in American Foreign Trade: A Case of Ill-Defined Private Rights and Unrefined Public Power, 70 Dick. L. Rev. 480 (1966); Scharpf, infra note 381, at 578 n.218; Timberg, Wanted: Administrative Safeguards for the Protection of the Individual in International Economic Regulation, 17 AD. L. REv. 159 (1965).

275. 5 U.S. (1 Cranch) 137 (1803).

276. Id. at $165-66$.

277. 225 F.2d 938 (D.C. Cir. 1955).

278. Id. at 944 . An analogy is to be found with respect to treaties. U.S. CoNST. art. $11, \S 2$, cl. 2, dealing with the making of treaties, concerns the public order question of when a treaty will be effective within the United States. On the other hand, U.S. CoNST. art. VI, cl. 2, which declares treaties to be "the supreme law of the land," and which thus governs the relationship of treaties and individual or private rights, concerns at least in part the private order; $c f$. Restatement OF Foreign AfFaiRs $\S \S 140-41$. This dichotomy is clearer in the United Kingdom where the executive makes treaties, which are effective to bind the government as a matter of constitutional law, but Parliament must pass a law and give them "domestic" effect if they are to affect private British rights. See H. Steiner \& D. Vagts, TRansnational Legal Problems 415, 502-05 (1968) [hereinafter cited as Steiner \& VAGts]. 
means of inevitable friction incident to the distribution of the governmental powers among three departments to save the people from autocracy." 279 At least one member of the Supreme Court has acknowledged this non-application of the separation of powers doctrine to foreign affairs: "in our intercourse with . . . [foreign nations] . . . even the internal adjustment of federal power, with its complex system of checks and balances, are unknown . . . ."280 However, even in the core area, presumably the executive is subject to the Bill of Rights and other provisions of the Constitution protective of individual rights. ${ }^{281}$

Where it is not the rights of particular individuals that may be involved, but the collective rights of all or many citizens, the doctrine of the separation of powers applies in order to ensure a more democratic control. The power of Congress to declare war, although somewhat atrophied in practice, ${ }^{282}$ can be understood in these terms. Here, significantly, the full Congress rather than any committee will be principally involved. This involves the kind of general ${ }^{283}$ decision in which the Congress is more qualified to participate 284 than it is in decisions concerning the core area.

The general authority to withhold appropriations is another example of the application of the separation of powers to foreign

279. Myers v. United States, 272 U.S. 52, 293 (1926) (dissenting opinion); cf. C. MONTESQUIEU, THE SPIRIT OF THE LAWs (1949). "Political liberty . . . is a tranquility of mind. ... In order to have this liberty, it is requisite the government be so constituted as one man need not be afraid of another ... when the legislative and executive powers are united in the same person, or in the same body of magistrates, there can be no liberty." Id. at 281 . See also THE FEDERALIST No. 51 (J. Madison).

280. In re Neagle, 135 U.S. I, 85 (1890) (dissenting opinion). Conversely, in the domestic sphere, individual rights will normally be involved in the exercise of government power and the separation of powers therefore applies. See, e.g., Youngstown Sheet \& Tube Co. v. Sawyer, 343 U.S. 579 (1952).

28I. See Reid v. Covert, 354 U.S. 1 (1957); Geofroy v. Riggs, 133 U.S. 258 (I849); cf. United States v. Curtiss-Wright Export Corp., 299 U.S. 304,320 (1936).

282. See notes 110-17 supra and accompanying text (Part I).

283. See notes 189-90 supra and accompanying text (Part 1).

284. Senator Fulbright has acknowledged that the Senate as a practical matter is very poorly equipped to deal with day-to-day policy-making or to try to outguess the President in this field. On the other hand he believes "the Senate is very well equipped to deal with the longer-range, more basic questions' of foreign policy," and believes the Senate and House can "corne up with ideas on the periphery of foreign affairs" which the executive will miss. Kenworthy, The Fulbright Idea of Foreign Policy, N.Y. Times, May 10, 1959, § 6 (Magazine), at 74. Roger Hilsman has propounded a thesis of how national consensus is developed with respect to long term foreign policy issues, into which this concept of the Senate's function might well fit. See Hilsman, Congressional-Executive Relations. 
affairs. ${ }^{285}$ As we have seen, the precise extent of this power is not fully delimited, although it is exercised to limit the overall level of government expenditure and to prevent waste and.promote economy ${ }^{286}$ in order to limit taxes, a general public interest. Professor Bickel has indicated that, as a practical matter, because of the vast volume of executive activity which was "undoubtedly foreseen, Congress is forced to consider the purposes of appropriations in fairly by-and-large fashion. Congress normally exercises, therefore, a general policy control . . .."287

Congress' power to regulate foreign commerce, following the earlier precedent of the House of Commons, ${ }^{288}$ can be explained in terms of the individual interests involved and its proximity to domestic dynamics. Significantly, where international dynamics become involved, congressional power may, as has been demonstrated, yield to executive. 289

The rationale for Senate participation in the treaty power is not so clearly that of democratic control. Indeed, the history of the constitutional provision suggests that the Senate may have been given a role in order to protect states' rights, although the locus of the treaty power shifted throughout the Constitutional Convention. At one point the Senate was to make treaties by itself. The final two-thirds Senate vote requirement for ratification was in fact contrived to protect certain regional interests. ${ }^{290}$ It may be this history which explains the increasing shift to executive agreements, at least the more "democratic" congressionally-authorized variety. ${ }_{.}^{291}$

Congressional control over administrative detail can probably be explained in terms of congressional expertise; this may not extend, however, to such questions as the rank and size of embassies abroad, or questions of unitary management. A similar explanation can be offered with respect to financial detail. Congressional expertise and

285. Compare congressional powers over the military establishment, note 110 supra and accompanying text (Part 1).

286. See McGuire, Constitutional Control over Public Moneys, 2 FED. B. Ass'N J. 187 (1935).

287. Hearings, Separation of Powers 246-67.

288. WRIGHT-FOREIGN RELATIONS 143.

289. See notes $145-48$ supra and accompanying text (Part 1). Congress has also voluntarily delegated authority over foreign commerce to the executive for reasons of practicality. Sayre, The Constitutionality of the Trade Agreements Act, 39 Colum. L. REv. 751,756 n.10 (1939).

290. D. Cheever \& H. Haviland, American Foreign Policy and the Separation of POWERS 8 (1952).

291. McDougal \& Lans. 
democratic control of the tax burden might be balanced against the factors of executive expertise discussed above.

\section{The Foreign Aid Program}

The Marshall Plan, ${ }^{22}$ and its immediate precedessor programs of aid to Greece and Turkey, ${ }^{293}$ represented a rather radical departure for peacetime United States foreign policy. "Modern American foreign policy began in Greece . . . in 1947 . . . The Truman Doctrine ended all U.S, aloofness in the internal affairs of nations in other hemispheres. Greece set the tombstone on isolationism."'294

Although one authority has written that "[m]ost observers ... agree that, without the Marshall Plan, Europe would have fallen into economic and political chaos. . . ",295 that Plan and successor aid programs have always been surrounded by controversy. ${ }^{296}$ The dependence of the executive on the Congress for large amounts of money ${ }^{297}$ for the foreign aid program undoubtedly increased the practical power of the Congress over this aspect of foreign affairs and possibly over its conduct generally. One commentator has stated that "the impact of the spending power on United States post-war foreign policy has changed the relationship between the President and the Congress in the foreign affairs field. The result has

292. Economic Cooperation Act of 1948, ch. 169,62 Stat. 137.

293. The so-called Truman Plan, Act of May 22, 1947, ch.81,61 Stat. 103. 5.

294. Sulzberger, Foreign Affairs: Where It All Began. N.Y. Times, Aug. 28, 1968, at 46, col.

295. Montgomery, The Political Decay of Foreign Aid. 57 YAle Review 6 (1967). Senator Fulbright once called "the Mutual [Security] Program" "one of the keystones of our foreign policy." Fulbright, 20th Century 4.

296. E. MASON, Foreign Aid AND Foreign Policy (1964). One mark of this has been the continued changes of format, concept, and administration for the program, a process that has not ended yet. Thus the program or administrating agency have been at one time or another in roughly chronological order: Economic Cooperation Administration, Point IV Program, Mutual Security Administration, Foreign Operations Administration, Intcrnational Cooperation Administration, Development Loan Fund, and Agency for International Development. In May, 1969, President Nixon, while proposing to continue AID, proposed yet another vehicle-the Overseas Private Investment Corporation which he has now established. 83 Stat. 809-18, Pub. L. No. 91-175, $\S \S 237-40^{\circ}$ (Dec. 30, 1969). The continued talk of multilateralization of aid also reflects, in a sense, an effort to change the program's format and administration.

297. For example, economic assistance for the period 1949-52 was $\$ 19,541$ million. Hearlngs on S. 2347 Before the Senate Comm. on Foreign Affairs. 91 st Cong., Ist Sess. 243.44 (1969). Cf. note 303 infra for more recent levels. 
been to lessen the significance of the treaty power and the President's possession of the diplomatic powers." 298

With the successful conclusion of its aid programs in Europe, the United States' foreign aid program has shifted almost exclusively to the emerging, less developed countries of Asia, Africa, the Middle East, and Latin America. ${ }^{299}$ The Marshall Plan was intended to rebuild European economies, counter the Soviets, and enhance America's security. Our aid to underdeveloped countries is similarly based on the notion that the internal development of the society and economy of such countries will ultimately contribute to their and the world's stability and, of course, to our own $3^{300}$ One would have supposed that our policy of promoting long term stability through the internal development of the nations of the world might be distinguished at least conceptually from the more immediate tasks of keeping internal and external peace. Yet, our seemingly sensible long term economic and social policy has, in the minds of some, become oddly linked with our military misfortune in Vietnam, ${ }^{301}$ and it must be recognized that while the development needs of the less developed

298. Note, The United States Congress and Development of Foreign Policy, 2 INT. L.Q. 658 (1948). Because of the House of Representative's initiative in tax and revenue matters, another consequence has been some increase in its role in foreign affairs relative to the Senate. The Marshall Plan has also been credited with another innovation, the emergence of bipartisanship in foreign affairs. "Political partisanship was wiped out during the Congressional debates on the Administration's Marshall Plan proposals." Id.

299. AID, ANNuAl Report to the Congress, Fiscal Year 1969 at $28-41$ (1970).

300. Thus, Robert McNamara has written of our interests in Asia:

We have therefore a vital strategic interest in [the nations of the western Pacific], an interest we cannot ignore . . . Our role in this process [of efforts applied to the growth of political, economic, and military strength] will be particularly important. American policy toward Southcast Asia and the Southwest Pacific area must blend concern and restraint as all help the East Asian nations to build among themselves the true security that flows from economic and social progress. R. MCN Amara, The Essence of SECURITY 22-23 (1968).

301. See, e.g., Senator Fulbright's statement: "One example, among other reasons given, for justifying the intervention in Vietnam was the fact that we had foreign aid programs there, and from this [the executive] seemed to deduce certain authority to intervene militarily." Hearings on S. Res. 15/ Before the Senate Comm. on Foreign Relations. 90th Cong., Ist Sess. 42 (1967) [hereinafter cited as 1967 Hearings]. Senator Fulbright was encouraged by statements such as the following by Secretary of State Rusk, "We are committed to assist South Vietnam . . . [for many reasons including] the aid approved by bipartisan majorities [of Congress] . . ." Id. at 119.

302. See generally Commission on International Development (Pearson Commission), PARTNERS IN DEVELOPMENT (1969). 
countries become more urgent, ${ }^{302}$ foreign aid has sunk to a relatively low national priority at this time. ${ }^{303}$ Nevertheless, our foreign aid has meant a great deal to its recipients and is an important factor in their countries' political life. As Robert F. Kennedy once observed, "In some countries of the world, the most powerful single voice is that of the AID administrator, with the Ambassador ... having relatively little power.' '304

The principal legislation presently governing the foreign aid program is the Foreign Assistance Act of 1961, as amended. ${ }^{305}$ It purports to give the President authorization to conduct the various programs; ${ }^{306}$ prescribes operating standards, criteria, and procedures;

303. The appropriations figures over the last few years tell the story:

$\begin{array}{cc}\text { Foreign Economic } \\ \text { Aid Appro- } \\ \text { priations } \\ \text { Ycar } & \text { (In Billions) } \\ 1962 & \$ 2.314 \\ 1963 & 2.603 \\ 1964 & 2.000 \\ 1965 & 2.195 \\ 1966 & 2.048 \\ 1967 & 2.144 \\ 1968 & 1.895 \\ 1969 & 1.380\end{array}$

Foreign aid "in effect, got caught in the backlash of the war in Vietnam." N.Y. Times, Apr. 25, 1969, at 27, col. 7 (city edition) (speaking of appropriations for the International Development Association, an affiliate of the 1BRD).

304. R. Kennedy, ThiRTeEn Days 114 (1969). Then Undersecretary of State Richardson stated, in speaking of our foreign aid, that "Economic development reprcsents our single strongest tie to the developing nations . . . N.Y. Times, June 10, 1969, at 7, col. 1.

305. 22 U.S.C. § 2151 et seq. (1964). Other relevant legislation includes the Foreign Assistance and Related Agencies Appropriations Act, 84 Stat. 5 (1970) [hereinafter referred to as 1970 Appropriations Act or FAAA]; and the Agricultural Trade Development and Assistance Act of 1954, as amended. 7 U.S.C. $\$ 1691$ (Supp. 1V, 1968) (hereinafter referred to as P.L. 480]. See also The Peace Corps Act, as amended, 22 U.S.C. \$ 2501 (1964); cf. ExportImport Bank Act of 1954, as amended, 12 U.S.C. $\S 635$ (1964); the Mutual Defense Assistance Control Act of 1951, as amended, 22 U.S.C. $\S 1611$ (1964) [hereinafter referred to as the Battle Act]. The full text of these acts, and other relevant legislation, is available in STAFF OF THE Senate Committee on foreign Relations and House Comm. on Foreign Affairs, Legislation ON Foreign Relations 91 st Cong., 1st Sess. (1970).

306. American foreign economic assistance has consisted of a number of diffcrent programs. These have included large scale commodity assistance on a grant basis, e.g., Mutual Security Act of 1954, 68 Stat. 832, repealed 22 U.S.C. $\$ 2151$ (1964) [hercinafter cited as MSA], and now on a loan basis, FAA $\S 201$; development loans for capital projects, e.g.. FAA $\S 201$; technical assistance, FAA $\S 211$; local currency loans and grants, P.L. 480, $\S 104$; several kinds of guarantees of United States investments, FAA $\S 221$; and supporting assistance, FAA $\S 401$. There are also programs of military assistance with which this article is not 
contains administrative provisions; and includes many of the restrictions ${ }^{307}$ on the President's discretion which are the subject of this article. ${ }^{308}$

\section{The Application of The Standards}

\section{Foreign Aid Within the Independent Powers of the President}

Although this article has focused on the President's exclusive powers rather than his merely independent ones, it seems clear that many aid decisions relating to the existence, content, and conduct of our relations with foreign countries fall within the President's independent powers. ${ }^{309}$ The decision to initiate aid to one or more

primarily concerned. See, e.g., FAA $\S 50 I-24$. It should be recognized, however, that the line between economic and military assistance has not always been crystal clear. Economic assistance has often bcen given to strengthen a country in many ways, including militarily. See former "defense support" which was provided under Mutual Security Act of 1954, as amended. MSA $\S \S 131-32$; $c f$. FAA $\S 40 I$ (supporting assistance provided to "support or promote economic or political stability"). So, too, military assistance can be used to promote economic development. FAA $\$ 502$ (civic action).

307. While the executive has not publicly resisted such restrictions on constitutional grounds, it has, of course, pleaded for flexibility on practical grounds, both with respect to technical and political restrictions. MorRow, supra note 255, at 35-37. And the Congress has to a considerable extent left the President flexibility through waivers in the "national security interest" (FAA $\$ 620(d)$ ); through modifying proposed mandatory provisions into more loosely worded ones (FAA $\$ 620(0)$ ); through sense of Congress provisions (former "mob action" provision, text accompanying note $33 \mathrm{I}$ infra); and through dropping others entirely (partition of Ireland, note 332 infra). It may be that it has done so, not only in response to executive pleas for flexibility on practical grounds, but because it sensed the possibility of "constitutional" problems. Cf. House Report No. 818, note 329 infra, at 166; 108 CoNG. Rec: 13153-54 (1962) (Congressman Judd regarding FAA § 620(e)).

308. The several classes of provisions in the FAA and other foreign aid legislation are discussed in Wilkins, Legal Norms and International Economic Development: The Case of the Cuba Shipping Restriction in the United States Foreign Assistance Act, 55 CALIF. L. REv. 977 (1967).

Has all this legislation been "necessary," as a constitutional matter? Certainly much of it deals with administrative detail, including operating procedures and personnel matters, on which Congress has legislated for other foreign affairs agencies including the Department of State. As a practical matter, substantial appropriations might not have been available without substantial legislation. It was apparently also believed that substantial legislative involvement with the substantive aspects of the program would enable it to acquire "deeper roots and possess greater stability than one formulated solely by the President and the State Dcpartment." See 2 INT. L.Q., supra note 298 , at 659 . Notwithstanding these practical factors it would seem that to the extcnt that the program and its conduct is based on the independent foreign affairs powers of the President, the legislation is technically "unnecessary."

309. Scnator Fulbright has in fact assumed that much of foreign aid falls within the traditional corc area. . Hearings. Separation of Powers 44.

Presumably aspects of other post World War 11 activitics, for example, intelligence, information, disarmament, atomic energy exchanges, military sales, surplus agricultural sales, 
countries would seem to be such a decision. ${ }^{310}$ The fact that Congress can withhold appropriations and frustrate the executive decision is little different from Congress' power to frustrate the treaty power by the withholding of appropriations."11 Similarly, Congress can, in theory, withhold all appropriations to the State Department and effectively curtail our foreign relations, ${ }^{312}$ but this does not mean that the President has no independent foreign affairs powers. ${ }^{313}$

\section{Exclusive Powers of the President}

The restrictions in present and past foreign aid legislation fall into several classes.

a) Directions to the President. Just as Congress may not direct the President to exercise his powers within the traditional core area, ${ }^{314}$ so it would seem that it may not do so with respect to powers within the "new" core area of foreign aid. In 1950 the Congress sought in the Omnibus Funds Bill ${ }^{315}$ to direct the President to make a loan of $\$ 62.5$

trade, cultural exchanges, possibly tax, antitrust, export control, and the operations of the Export Import Bank may fall within such independent powers.

310. The Marshall Plan was an executive initiative. G. KENNAN, supra note 268, at 326.

3I I. Consider, for example, the executive's difficulties over U.N. contributions. Nobleman, Financial Aspects of Congressional Participation in Foreign Relations. 289 ANNALS AM. ACAD. Poi. \& Social Sci. 145, 163 (1953) [hereinafter cited as Nobleman].

312. See notes $85-87$ supra and accompanying text (Part 1 ).

313. Professor Bartlett would therefore seem in error in the following testimony:

1 remember an instance not long ago, not in the present Administration, in which the President was asking the Congress for appropriation of money for foreign aid, and he said at his press conference that he would not be able to carry out the foreign policy of the United States unless Congress appropriated the amount that he had asked for for foreign aid. I think this is a fine example of this sort of a problem, because 1 would suggest that if the President asks for, say, $\$ 1$ million for foreign aid to a given country, and the Congress is not convinced that this is right and therefore does not appropriate the money, then it is not the foreign policy of the United States to give that eountry $\$ 1$ million. This is the erux of the matter. It does not become the foreign policy of the United States simply by the presidential edict. 1967 Hearings 24.

The Congress has entertained similar conceits with respect to more traditional areas. Thus, in 1867, after a treaty had been concluded for the purchase of Alaska, the Congress sought to amend the appropriation and implementing legislation to read, "that the powers vested by the Constitution in the President and Senate to enter into treaties with foreign governments do not include the power to complete the purchase of territory before the necessary appropriations shall be made therefor by act of Congress . . . Nobleman 152. The amendment was defeated by two votes.

314. One provision of the FAA seems to attempt just that. FAA $\S 60 \mathrm{I}(\mathrm{b})(2)$ provides that "the President shall . . . accelerate a program of negotiating treaties for commerce and trade, including tax treaties, which shall include provisions to encourage and facilitate the flow of private investment . . . ." This seems improper.

3I5. Act of Sept. 6, 1950, ch. 896, 64 Stat. 595. 
million to Spain. President Truman chose to treat the direction as an authorization: "I . . . feel obliged to comment upon the provision of the bill which authorizes loans for the purpose of assistance to Spain. I do not regard this provision as a directive, which would be unconstitutional, but instead as an authorization, in addition to the authority already in existence under which loans to Spain may be made."'316

b) Congressional and Committee Vetoes. The executive has chosen to challenge restrictions on foreign aid on much the same grounds as those in domestic legislation. Thus, President Johnson, in signing the 1964 amendment to P.L. 480, chose to treat, as "report and wait" requirements, two "committee veto" provisions. One provided that all local currency grants were subject to disapproval of the agriculture committees within 30 and, in some cases, 60 days of transmission, and the other required the approval, by a committee partly composed of Congressmen, of local currency loans made at interest rates below the cost of funds to the Treasury. He stated:

In recent years four Attorneys General of the United States have held that legislative provisions vesting in congressional committees the power to approve or disapprove actions of the executive branch are unconstitutional. The Acting Attorney General now advises me that a provision vesting such power in a committee made up in part of Members of Congress stands on no better footing. Both such provisions represent a clear violation of the constitutional principle of separation of powers. This is the position taken in similar cases by President Eisenhower, President Kennedy, and by myself. ${ }^{317}$

President Kennedy had earlier instructed the Administrator of AID that a requirement that deobligated funds only be reobligated if there were no disapproval within 60 days by Congress and the appropriations committees was

unconstitutional either as a delegation to Congressional committees of powers which reside only in the Congress as a whole or as an attempt to confer executive powers on the committees in violation of the principle of separation of powers prescribed in Articles I and II of the Constitution. Previous

316. The President continued, "Spain is not, and has not been, foreclosed from borrowing money from this Government. Money will be loaned to Spain whenever mutually advantageous arrangements can be made with respect to security, terms of repayment, purposes for which the money is to be spent, and other appropriate factors and whenever such loans will serve the interest of the United States in the conduct of foreign relations." Nobleman 160.

317. He continued: "However, 1 appreciate the desire of the Congress to be informed and to be consulted on the operation of all aspects of the Public Law 480 program, and 1 am directing that executive officials see that this is done." 2 PUBLIC PAPERS OF THE PREsidents: Lyndon B. JOHNSON, 1963-1964 at 1250 (1965). 
Presidents and Attorneys General have objected to similar provisions permitting a committee to veto executive action authorized by law. ${ }^{318}$

More recently there has been included in the appropriations act a provision that "no part of this appropriation [for technical assistance] shall be used to initiate any project or activity which has not been justified to Congress . . .."319 A similar provision exists with respect to international organizations and supporting assistance. ${ }^{320}$ During fiscal year 1968 AID treated "justify" as a "report and wait" requirement. However, the House appropriations subcommittee indicated that this was a "committee veto" type provision, and it has in fact disapproved certain projects. ${ }^{321}$

In 1961, then Assistant Attorney General Katzenbach suggested, but only within the executive branch and not publicly, that a veto device on foreign aid might be especially improper because foreign affairs were involved. The provision concerned was a proposed amendment by Senator Dirksen to section 20I, S. 1983, which, although waivable, would, inter alia, have given Congress the power by concurrent resolution to bar particular loans of over $\$ 5,000,000 .{ }^{322}$ Mr. Katzenbach wrote Theodore Tannenwald, then Special Assistant to the Secretary of State, on August 23, 196I, that "the clause may well be thought to violate the doctrine of the separation of powers insofar as it interferes with executive authority. This difficulty is the more serious where the authority has an independent constitutional

\footnotetext{
318. He continued.

I concur in these views. However, I consider it entirely propet for the committees to request information with respect to plans for the expenditures of appropriated funds, and I recognize the desirability of consultations between officials of the executive branch and the committees. It is therefore my intention, acting on the advice of the Department of Justice, to treat this provision as a request for information. You are therefore requested to keep the appropriations committees fully informed of any reobligation of prior year funds. Public Papers of the Presidents: John F. Kennedy, 1963 at 6 (1964). See Chayes, A Common Lawyer Looks at International Law, 78 HARv. L. Rev. 1396, 1404 (1965) [hereinafter cited as Chayes].
}

319. See FAAA, Title I, Economie Assistance, cl. 1 .

320. Id. cls. $1 \& 7$.

321. The fact that AID has aequiesced in this, in contrast to the rather consistent exeeutivc objection to such devices in domestic and other AID cases, suggests the current weakness of the foreign aid program within the Congress.

322. Senator Gore had stated of this proposal, which was eventually defeated: "A determination upon a given development loan which may not involve many policy questions is in fact an executive function. Should Congress undertake to exercise veto power over a particular loan, it would, it seems to me, be undertaking to that extent to partake of the executive function * 107 Cong. Rer 15232 (1961). 
basis found in the exclusive presidential power to conduct foreign relations." ${ }^{323}$

c) Executive Secrecy. As already noted, executive secrecy may be equally applicable to domestic and foreign affairs, but it has been especially asserted with respect to the latter. Section 624(d)(7) of the Foreign Assistance Act ${ }^{324}$ requires the delivery of certain documents and information to certain committees of Congress or the General Accounting Office. Upon failure to do so, disbursements to the Inspector General for Foreign Assistance-an official in the State Department-are to cease, although the-President may "personally" waive this. For fiscal year 1960, section 533A(d) of the Mutual Security Act, ${ }^{325}$ a predecessor, did not contain this waiver authority. When President Eisenhower refused to deliver certain documents to the House Appropriations Subcommittee, notwithstanding the absence of a waiver authority, and directed the Secretary of the Treasury to pay the Inspector General, the issue was joined. The Attorney General gave an opinion ${ }^{328}$ in which he sought to avoid the constitutional issue. But he went on to say that if the issue could not be avoided, it was his opinion that the section in question was "plainly invalid" and "unconstitutional."327 The Attorney General implied that the involvement of foreign affairs reinforced the President's right. ${ }^{328}$ Senator Robertson, in explaining a proposed but unsuccessful

323. Letter from Nicholas deB. Katzenbach to Theodore Tannenwald, Aug. 23, 1961 (copy in author's possession); cf. FAA $\S 617$, which permits Congress by concurrent resolution, to terminate "[a]ssistance under any provision" of the FAA. This presumably includes the entire program, or aid to any particular country. Mr. Katzenbach also challenged this provision in 1961 in his letter to Mr. Tannenwald, although it has been the law since 1948:

The reasoning behind Professor Corwin's argument that delegated powers may be conditioned as the Congress sees fit may not apply to the instant provision. As is pointed out below, we are hcre dealing with situations in which the President has specific Constitutional powers of his own. The possibility that the concurrent resolution device might be used to intrude upon the Presidential power to conduct foreign relations may distinguish this situation from others.

Senator Javits has said of concurrent resolutions:

Use of this device to compcl Executive action or to provide for Congressional participation in the details of Executive administration of Congressionally granted authority would raise very grave constitutional doubts indeed, since they could well be construed as invasions of the Executive powers of the President. (He goes on to say that $\S 617$ does not raise this problem). 107 CoNG. Rec. 13989 (1961).

324. FAA $\$ 624(d)(7)$.

325. MSA \& 533(A)(d).

326. 41 OP. ATt'Y GEN. 507 (1960).

327. Id. at 530.

328. Id. at 519-20. 
amendment to the above statutory provision which would have permitted the President to withhold information in certain circumstances, stated: "If the President, in keeping with the wellestablished principle under the Constitution of the right of the President to handle foreign policy, decides that the disclosure of some phase of foreign policy would be against the public interest, he can so certify, and the Congress will not be able to get the information.' The matter was in fact resolved and the confrontation ended with the inauguration of President Kennedy, who instructed the documents to be shown to the subcommittee chairman but not its members, which apparently was satisfactory to the chairman. ${ }^{330}$

.d) Pressure on the Traditional Core. Area. We have seen that conditions on appropriations that put pressure on the executive with respect to the traditional core by the threat of withholding appropriations for the conduct of such core are improper. ${ }^{331}$ It would seem equally clear that such pressure on the traditional core, by threat of withholding appropriations for the conduct of aid, is also improper. Thus, a requirement that the President terminate our diplomatic relations with Russia, or India, or South Vietnam, as a condition of the availability of any aid appropriation, presumably would be improper. In 1950, the House in fact passed an amendment which was dropped in conference that would have terminated assistance to the United Kingdom until Ireland ceased to be partitioned. ${ }^{332}$ Certainly this would have put pressure on the President's recognition power.

A few current provisions come close to applying such pressure. Section $620(t)$ of the Foreign Assistance Act provides that no aid may be furnished to a country with whom diplomatic relations are severed until such relations are resumed. Although it is doubtful that aid would be furnished to a country with which the United States did not have diplomatic relations, an exception might be emergency relief, and section 639 of the Act in fact permits this. ${ }^{333}$ Section $620(\mathrm{i})$, which

329. House Committee on Government Operations, availability of Information from Federal Departments and Agencies, H.R. Rep. No. 818, 87th Cong., Ist Sess. 165 (1961).

330. Chayes 1403. A similar provision in the Mutual Security and Related Agencies Appropriation Act of 1961,74 Stat. 776, $\S 101$ (d). called for the termination of aid to a country where documents with respect to it wcre not delivered. H.R. REP. No. 818, supra note 329 , at 166.

331. See notes 149-215 supra and accompanying text (Part I).

332. Thorp, supra note 235. at 209.

333. FAA \& 639. 
bars assistance to "aggressors," that the President consider terminating assistance to a country which permits or fails to prevent mob action against "United States property," 335 may be considered as putting pressure on some rather traditional core area decisions-recognition of belligerency and making of protests.

e) Pressure on the Traditional and New Core Areas. FAA section $620(\mathrm{e})(1)$, the so-called Hickenlooper Amendment, ${ }^{336}$ puts pressure on both the traditional and new core areas. It provides, in essence, that aid be suspended to any government when that government or a subdivision thereof has expropriated an American national's property and has not taken appropriate steps towards compensation within six months of the taking. The effect of this section, which has been called a "serious encumbrance on the formulation of effective foreign policy." 333 is to put pressure on the executive to espouse a claim-an invasion of the traditional core area-or, in the alternative, to require the suspension of aid-an invasion of the new core area. This latter can be more deleterious to our relations than a failure to ever commence aid, especially because of the manner in which this section may be brought to bear to settle a contractual or commercial dispute over which there may be genuine differences of view. Although Ambassadors often make plain that they are under congressional compulsion and that $620(\mathrm{e})(\mathrm{l})$ may not be waived, local governments are often incredulous at this. ${ }^{338}$ Certainly, in today's world the termination of aid can have greater significance than the suspension of diplomatic relations or the formulation of a treaty. ${ }^{339}$

334. FAA § 620(i).

335. FAA § 620(j).

336. See note 4 supra and accompanying text (Part 1). FAA § 620(e)(1) is to be distinguished from FAA $\S 620$ (e)(2), the so-called Sabbatino Amendment, sometimes also referred to as the Hickenlooper Amendment, which was enacted to alter the result in Banco Nacional de Cuba v. Sabbatino, 376 U.S. 398 (1964), involving the application of the "act of state" doctrine; compare P.L. 480, § 410 , and Sugar Act of 1948, 7 U.S.C. $\S 1158$ (c) (Supp. IV, 1969), both of which contain provisions similar to FAA $\S 620(\mathrm{e})(1)$.

337. "Transition" memorandum prepared for President-elect Nixon, December 1968. (copy in possession of author).

338. See Ceylon Daily News, Feb. 11, 1963, at 6, col. 1, for the reaction of the Ceylonese government to the threat of suspension of U.S. aid. Cf. FAA $\S 620(c)$, which may be waived, barring assistance to any government "indebted" to an American for goods and services.

The State Department had traditionally avoided the assertion of contract claims. Restatement § 212 , Reporters' Note, Steiner \& VaGts 415 . This is possibly a result of the difficulties involved in the resolution of these claims. Jennings, State Contracts in International Law. 37 BYIL 156 (1960).

339. The termination of our aid to, for example, Peru, Brazil, or Argentina, would certainly 
The origins of the 1963 Hickenlooper Amendment have been traced ${ }^{30}$ lt was pushed very hard by an American company whose property had been expropriated by the Brazilian state of Rio Grande do Sul. While by its terms it cannot be waived, it is not clear how seriously the executive takes it, although the provision has now been applied, or its application threatened, in many other countries.311 Former Deputy Legal Advisor Lowenfeld remarked in 1967 that "it would be very difficult to establish or maintain an Alliance for Progress if every investment dispute, large or small, threatened to terminate the aid program for an entire country." ${ }^{362} \mathrm{He}$ seemed to conclude that the executive must therefore apply a "loose non-rule" to these matters, although recognizing "Congress has opted against" this. ${ }^{3+3}$ Possibly it is regarded as an unconstitutional congressional fait accompli. Its unconstitutionality has not, however, been asserted by the executive.34 FAA section $620(\mathrm{e})(1)$ is, perhaps, one of the

be of significance to our continuing relations with them. See, e.g. N.Y. Times, Dec. 8, 1968, at 25, col. 1 (city edition) ("Peru Aide Warns U.S. on Pressure"); $c f$. President Kennedy's remarks about this section when it was first proposed:

Nobody has ever questioned the right of any government to seize property, providing the compensation is fair.

The United States is involved with the Brazilian Government in attempting to adjust this matter. I can think of nothing more unwise than to attempt to pass a resolution at this time which puts us in a position not of disagreement with a governor of a state who is not particularly our friend, but instcad, really, with the whole Brazilian nation, which is vital and which is a key and with which we must have the closest relations. . . .

And I must say that if you look at the map and realize the vitality of Brazi-l think that we ought to keep a sense of proportion.

We don't want to make those who dislike us work easy by reacting to things which happen in a way which strengthen[s] them and weakens the influence of the United States. N.Y. Times, March 8, 1962, at 14, col. 8.

340. Lillich, The Protection of Foreign Investment and the Foreign Assitance Act of 1962.17 Rutgers L. Rev. 405 (1963). Cf. STEINER \& VaGts 358.

341. The non-waivability of the section reflects the view of many American investors that the executive's espousal of their expropriation claims in the past has often not been as vigorous as they believed warranted. Although non-waivable, Secretary of State Rusk indicated that the executive could live with FAA $\S 620(\mathrm{e})(1)$. Lillich, The Protection of Foreign Investment and the Hickenlooper Amendment, 112 U. PA. L. REv. 1116, 1127 (1964).

Countries where the section has becn applied, or its application thrcatened, include Argentina, Ceylon, Guinea, I ran, and Peru.

342. Lowenfeld, Diplomatic Intervention in Investment Disputes, 1967 AM. Soc. 1NT. LAW Proceedings 96, 98.

343. Id. at 102.

344. The question of the constitutionality of $\S 620(\mathrm{e})(1)$ is touched on in Comment, Angentina and the Hickenlooper Amendment, 54 CALIF. L. REv. 2078 (1966). 
"regrettable congressional incursions" to which Senator Fulbright has referred. ${ }^{345}$

f) Pressure and Restrictions on the New Core Area. Section $620(\mathrm{e})$ is just one of a number of provisions which bar, require the termination of, or otherwise inhibit the furnishing of aid to specified countries or classes of countries. ${ }^{346}$ Thus aid is wholly barred or otherwise restricted to, among others, Cuba or a country which assists $\mathrm{Cuba}^{347}$ unfriendly or Communist countries, ${ }^{348}$ the UAR, ${ }^{349}$ aggressors, ${ }^{350}$ countries seizing American fishing vessels in international waters, ${ }^{351}$ countries trading with or permitting ships bearing their flag to trade with Cuba or North Vietnam ${ }^{352}$ and countries trading in certain items with Bloc countries. ${ }^{353}$

345. "These mandatory restrictions, it is true, impose a degree of rigidity on the Executive and constitute a regrettable congressional incursion on matters of the day-to-day conduct of policy." Hearings, Separation of Powers 44.

346. The wording of the provisions vary. Some (l) bar the "provision" or "furnishing" of aid (e.g.. FAA $\$ \S 620(\mathrm{a})(1), 620(\mathrm{f})$ ); others (2) require the "suspension" or "termination" of aid (e.g., FAA $\S 620(\mathrm{e})(1))$. The overall effect will be the same, except that the latter may cut off disbursement under existing obligations, e.g., loans, whereas the former may not. There are other variations: some provisions bar aid to "countries," e.g.. FAA § 620(f); others to "governments," e.g., FAA § 620(a); this can mcan a differenee. Also, the provisions may be of varying mandatory quality. See note 375 infra.

347. FAA § 620(a).

348. E.g.. FAA $\S \S 201(\mathrm{~b}), 211$ (a) (friendly countries), 620(b), 620(f).

349. FAA $\S 620(p)$ and FAAA $\S 117$.

350. FAA \& 620(i). See text following note 333 supra.

351. FAA $\S 620(0) ; c f \S 5$ of the Fishermen's Protective Act of 1967, 22 U.S.C. $\S 1971$ (Supp. IV, 1969), amending 22 U.S.C. §§ 1971-76 (1964).

352. FAA $\S 620(a)(3)$ and FAAA $\S 107$, with respect to Cuba, and FAA $\S 620(n)$, and FAAA § 116 with respect to Vietnam, have barred aid to the United Kingdom, Yugoslavia, Cyprus, Malta, and Hong Kong. Transition memorandum, supra note 337. One authority had this to say about the Vietnam provision:

Similar Congressional restrictions in other fields have had serious repercussions overseas. The "trading with the enemy" clause in the recent foreign aid legislation provides that the United States cannot offer assistance to any nation that trades with Cuba or North Vietnam. On the surface, it appears cntirely reasonable to refrain from aiding those who aid your enemy, but unfortunately the law allows the President no discretion to make an exception even when it is clearly in the national interest to do so. One result was that the United States had to cut off its programs of "building bridges to the East" in Yugoslavia because that country had sent medical supplies to North Vietnam. Normally medical supplies are not considered contraband under international law; and their interdiction, even is they were sometimes used for the treatment of military personnel, surely does not advance American purpose very much. But it clearly injures the American position in Eastern Europe and throughout the Communist world when, for a trivial reason, it is no longer possible to encourage favorable developments in a nation that bas already shown other East European satellites how to defy Moscow, that has entered into a significant dialogue with the West, and that has markedly turned toward entrepreneurial 
Based on an analogy to restrictions on the President's recognition or diplomatic relations power, these provisions quite clearly seem constitutionally infirm. It has been indicated previously that aid relations may count for more today than traditional diplomatic ones. ${ }^{354}$ To worsen the impropriety, some of these provisions also put pressure on the traditional core area.

There are less drastic measures which can place pressure on the new core area. Thus FAA section $620(\mathrm{~h})$ requires the President to adopt regulations, which he has done, which limit fairly severely 355 the possibility of joint Communist Bloc-United States projects. Such a restriction clearly limits the effectiveness of United States diplomacy in less developed countries, and vis-à-vis the Bloc. To be sure, AID has learned to "live with" this restriction. It is just one example of many, and AID might deny feeling any "pinch" on operations because of it. The fact is that if the executive were left free to devise its own policies, subject always to regard for congressional feelings, it might have developed more effective ones.

g) Administrative Detail. As we have seen, both the executive and Congress have expertise with respect to numerous aspects of administrative detail. Thus ordinary personnel requirements ${ }^{358}$ may very well be within the competence of the Congress. On the other hand, as we approach external matters the executive power should grow. Thus query whether FAA section 631 (a), which authorizes the President to maintain special AID missions overseas, is constitutionally "necessary." FAA section 631 (d), which provides that "wherever practicable . . . especially in the case of the smaller programs" economic assistance shall be administered by the embassy

competition and even permitted a degree of political liberalism. It is ironic that one aid project under consideration when the Congressional ban was announced was a $\$ 30$ million wheat sale that would have helped finance economic reform (featuring liberalization and decentralization) in Yugoslavia. Montgomery, supra note 295, at 11. The unfortunate consequences of United States withdraw al from the Prek Thnot Dam project in Cambodia in 1966 because of these provisions are described at $i d$. at $1-5$.

353. Battle Act; FAA $\S \S 107,109 \& 116 ;$ P. L. 480 § 103(d).

354. See note 304 supra. A statement made to Congressman Derwinski by an American ambassador that "modern diplomacy is 90 percent aid," seems an exaggeration. H.R. REP. No. 1587, 90th Cong., 2d Sess. 60 (1968).

355. AID MANUAL ORDERS $\S 1018.9$ (May 8, 1964).

356. E.g., FAA § 625.

357. As first proposed, this requirement would have been mandatory for all programs of less than one million dollars per annum. S. 1837, 89th Cong., 1st Sess. $\S 302(\mathrm{e})$ (1965). The requirement was dropped by the conference committce. H. REP. No. 811, 89th Cong., 1st Sess. 23-24 (1965). 
staff, seems of questionable propriety. ${ }^{357}$ And early legislation, ${ }^{358}$ which specified that any difference between the Secretary of State and the foreign aid administrator was to be resolved personally by the President, thus in effect barring a Presidential delegation of this task to the Secretary of State, may well have run afoul of the principles of "unitary management." 359

h) Financial Terms, Operating Procedures, and Procurement Provisions. The issue here seems to be a balance of traditional congressional competence and concern versus the degrce of impact on our external relations. Consider, for example, financial provisions such as the substitution of loans for grants and minimum interest rates on loans. ${ }^{360}$ These appear to be within more accepted bounds of the appropriations power, but can certainly restrict the executive in ways deleterious to aid relations. The terms of aid loans can have a serious impact on, for example, India's debt burden, her foreign exchange position, investment possibilities, and, hence, her economic development. ${ }^{361}$ To illustrate, if Congress were to prescribe a maximum 18 year term and minimum 6 percent interest, American aid loans would probably be prohibitive and aid relations with India seriously affected. Would it be unreasonable to say that while Congress may withhold funds entirely, once it appropriates them they must be free of such restrictions as this? While Congress can normally prescribe operating procedures, ${ }^{362}$ should it be completely free to do so if the same have a considerable impact on the effect of United States aid programs abroad? ${ }^{363}$ The burden which this might plaee on the conduct of foreign affairs suggests that perhaps Congress should not possess such freedom.

358. See Surrey, The Economic Cooperation Act of 1948, 36 CAltF. L. REv. 509 (1948); cf. Jewell, supra note 153, at 121.

359. See note 105 supra (Part I).

360. The FAA has no provision concerning the maximum term of a loan, although forty years is, as an administrative matter, AID's longest term. AID MANUAL ORDER $\S 1052.1$ (Oct. 9, 1968); cf. P.L. 480, § 106 (agricultural surplus dollar sales on maximum 20 year credit).

361. See The Economist, Jan. 4, 1969, at 50, cols. 2-3 (1ndia: Aid Crisis Hinders Growth).

362. See note 104 supra and accompanying text (Part I).

363. See, e.g., FAA $\S \S 201$ (b), 211 (a) (specifies criteria which President is to "take into account" in making particular loans and grants); FAA $\$$ 611(a) (technical and financial planning required before obligation of funds for certain purposes); FAA $\$ 611(\mathrm{~b})$, FAAA $\S 101$ (no water related project to be financed until certain Department of Interior costbenefit computations made); FAAA $\S 115$ (requires President to issue regulations, which he has done, to minimize use of non-American non-local nationals on construction jobs); FAA $\S \S 221-24$ (many technical and other limitations on investment guaranty programs). 
Possibly more controversial are provisions related to procurement and, arguably, at least partly within the commerce powers of Congress. These include the provisions of the Merchant Marine Act of $1936^{364}$ and FAA section 603 requiring 50 percent of all aid commodities to be shipped on American vessels, and FAA section 604(a), pursuant to which the President has brought AID commodity procurement to the point that it is 98 percent of United States origin. ${ }^{365}$ It might well be thought that the President's exclusive powers are applicable to some extent to these matters.

i) Categories, Line Items, and Other Niceties. The annual appropriations and authorizations for foreign aid are divided into categories such as development loans and technical assistance. ${ }^{366}$ In The past the executive has on occasion ignored such categories in military appropriations. Was this mere fait accompli or are such restrictions improper? If the President could properly ignore such restrictions, where would it stop? There must be some limit on the President's freedom. Presumably, the Congress can properly decide whether our aid will be on a bilateral rather than a multilateral basis. ${ }^{367}$

The line item is troublesome. Thus, if it is accepted that the prohibition of aid to certain countries is objectionable, ${ }^{388}$ Congress might resort to line items and specify the countries which will receive aid and, if it wished, amounts each will receive. Though largely avoided in recent years, this approach had been resorted to in the past. ${ }^{360}$ Arguably, such statutory specification should be deemed beyond Congress' power. In effect the line item is a "nicety" which should not be available if it in substance accomplishes what other forms of control, which are clearly improper, may not.

364. FAA § 601(b), 46 U.S.C. § 1241 (1964).

365. The Foreign assistance Program, Annual Report to the Congress Fiscal YeAR 1968, at 19 (1969); 'cf. United States v. Concentrated Phosphate Export Ass'n, 393 U.S. 199,202 n.5 (1968).

Compare FAA § 620 (d), whieh restricts assistance to productive enterprises whose output may compete with U.S. enterprise and AID MANUAL ORDER § 1016.1, which restricts aid to textile plants which are thought to be competitive with U.S. textile manufacturers.

366. FAA $\S 610$ gives the President limited authority to transfer funds between categories.

367. Cf. FAA $\S 205$ (10\% of development loans may be transferred to the IBRD, IDA,and IFC); FAAA, Title I, Economic Assistance, cl. 11 (no funds may be used to carry out FAA $\S 205)$.

368. See notes 331-53 supra and accompanying text.

369. Mutual Defense Assistance Act of 1949, § 303(a), 22 U.S.C. § 1571(7) (1964), specified amounts of aid for certain European countries and "general area of China." 
We have seen that Congress may not specify the rank of our emissaries to other countries and, analogously, it seems inappropriate that it should be able, within the total amount appropriated for aid, to designate amounts for each recipient country. At the present time legislation does not specify individual country "aid levels." To be sure the annual executive presentation may indicate such amounts. ${ }^{370}$ But such "presentations" are not deemed legally binding, although their flagrant violation may of course bring congressional retribution in subsequent years. FAA section 620(u) and FAAA section 119 require the President to "withhold economic assistance in an amount equivalent" to that spent on sophisticated weapons. ${ }^{371}$ The exact operation of such a requirement may be problematic.

Another set of provisions limits the number of countries to which particular categories of aid may be provided. ${ }^{372}$ Professor Montgomery wrote of the predecessors to these provisions: "Congress has unilaterally declared its intention to rid the United States of the burden of carrying the world on its shoulders. With no rationale other than sheer discouragement, it voted in October 1966 to limit development loans to only ten countries, supporting assistance to thirteen, and technical assistance to forty. ${ }^{3733}$ These restrictions are especially troublesome. It may very well be that the United States should concentrate its aid efforts, and Congress can certainly play a

370. In fact AlD's budget presentation has been on an illustrative basis; it has not presented all its actual proposed projects for each coming fiscal year for incorporation in the authorization and appropriations legislation. It has not only resisted the specification of amounts for particular project but for regions and counties as well.

371. FAA $\S 504(\mathrm{a})$; $c f$. FAA $620(\mathrm{~s})$, which calls for the termination of assistance to a country whose military expenditures materially interfere with its development.

372. FAA $\S 201(\mathrm{~b}) ; c f$. FAA $\S 211$ (a) (limits technical assistance recipients to 40 countries, with a $\$ 600,000$ exception for "self-help" projeets); FAA $\S 401$ (limits supporting assistance recipients to 12 countries); FAA $\S 504(2)$ (limits military assistance to 40 countries).

373. Professor Montgomery continued:

Fortunately, it also gave the President discretionary power to increase these numbers if he found it in the national interest to do so; which, obviously, he would have to do since in the previous ycars we had been offering aid to seventy-seven countries, none of which was prepared to abandon its claims for assistance. In an effort to concentrate aid programs, the United States now sends nearly 90 percent of its aid to twenty nations, and is replacing bilateral arrangements where possible by regional efforts. Even so, Senator Fulbright objected vigorously when the President found it in the national interest to exceed the statutory limit of sixty-six countries. Montgomery, supra note 295, at 10; cf.

Hearings, Separation of Powers 44.

These sections are technically subject to the FAA $\S 614(\mathrm{a})$ waiver authority but it is unlikely it will be used. As originally enacted these sections had express waiver authority, but this has now been deleted. 
significant role in the development of consensus on this. But surely the line as to the exact number of countries is for the executive. Who is to say that development loan programs for twenty countries is not too few? Could Congress reduce the number to five? ${ }^{374}$

It seems fair to conclude that those "niceties" which seek to accomplish indirectly what the Congress cannot do directly are forbidden "controls" and not mere extensions of the permitted power to withhold appropriations. To hold that Congress is without these "nice" powers is not to leave it helpless to check the executive."375

374. It might be argued that only the suddenness of a reduction to five, from say twenty, would be objectionable. This article maintains that the limitation itself is bad. There are yet other sorts of congressional restrictions. Thus, Congress has not refrained from seeking to impose statutory limits on our executive's participation in international agencies. The InterAmerican Development Bank [IDBA], \& 14(c), 22 U.S.C. § 2831(c) (Supp. III, 1968), requires the U.S. representative to vote against any Fund for Special Operations loans to a country which is in violation of the Hicklenlooper Amendment, FAA \& 620(e)(1), supra note 336; IDBA $\S 283 \mathrm{~m}$ (c) contains a similar provision with respect to the sa-called Symington Amendment, FAA $\S 620(\mathrm{~s})$. See Wilkins, supra note 308 , at $986 \mathrm{n} .35$; $c f$. the attempt by the House Banking and Currency Committee, on March 14, 1968, to direct the then U.S. executive director of the IBRD, Livingston Merchant, to vote against a loan to Greece. Hearings on World Bank Loan to NIBID of Greece Before the Subcomm. on International Finance of the House Comm. on Banking and Currency, 90th Cong., 2d Sess. (1968).

It is interesting to note that AID, as an administrative matter, has always taken the position that any AID funds channeled through international organizations pass free of most of the restrictions of the aid legislation.

Cf. Congressional approaches to appropriations for U.N. contributions, supra note 311; P.L. $84-885$, \& 5 (certain authority conferred on the Department of State is "not to be construed as granting authority . . . to participate in the activities of any international organization for more than one year without approval by the Congress"); FAA $\S 301$ (b) and FAAA, Title 1, Economic Assistance, cl. 5 (President "shall seek to assure that no [U.S.] contribution to the United Nations Development Program . . . shall be used for . . . the Government of Cuba, so Iong as Cuba is governed by the Castro regime"); FAA $\S 301$ (c) ("No contributions . . . shall be made [to the United Nations Relief and Works Agency for Palestine Refugees in the Near East] except on the condition that the United Nations Relief and Works Agency take all possible measures to assure that no part of the United States contributions shall be used to furnish assistanee to any refugee who is receiving military training as a member of the so-called Palestine Liberation Army"). Cf. FAA § 620(u) (President shall take into account a country's U.N. dues status in decision whether to provide aid).

375. For examples of such "checks" see notes 420-37 infra and accompanying text. It should be noticed that not all restrictions are non-waivable; that is, by their terms thcy cannot be waived by the President, and the general waiver provisions of FAA § 614(a) do not apply to them. Non-waivable provisions include, however, FAA § 620(e)(1); FAA § 620(i), text after note 333 supra; FAA § $620(\mathrm{~s})$, note 371 supra; and FAA § $620(\mathrm{k})$. Similarly, the Fisherman's Protective Act, $\S 5$, supra note 351 , and certain restrictions in P.L. 480 cannot be waived. For one critical year, $\S 533 \mathrm{~A}$ (d) of the Mutual Security Act, Act of July 24, 1959, Pub. L. No. 86$108, \S 401$ (h), 73 Stat. $253-54$, requiring the disclosure of documents, could not be waived, or at least the Comptroller General so maintained. See text accompanying note 325 supra.

To be sure, even the terms of non-waivable provisions are subject to interpretation and hence 
The Manner of Application of Constitutional Standards to FOREIGN AID

\section{Judicial Definition}

Judicial definition of the substantive area of the traditional core of foreign affairs, and the controls from which it is immune, has been incomplete. The reasons for this are several. Most core area decisions, as defined above, ${ }^{376}$ do not have a direct impact on individual rights. The remark of Martin F. Richman, then First Assistant, Office of Legal Counsel, Department of Justice, about committee vetoes seems applicable: "Of course, this sort of thing inherently is very hard to get into judicial frameworks. It is betwcen the executive and the legislative

to some executive discretion. See Panama Canal Co. v. Grace Line, Inc., 356 U.S. 309, 318 (1958). Thus, for example, the phrase "take into account" in FAA $\$ 620(s)$, note 37I supra, certainly provides a great deal of flexibility. Some, if not a great amount of, flexibility has been found in FAA $\S 620(\mathrm{e})(1)$. Thus, the direction that assistance be suspended to a "government" might permit loans to private borrowers in a country to continue. So too, the reguirement that "appropriate steps" be taken to compensate within six months, has permitted an interpretation that the commencement of good faith negotiations within that period, and not actual payment, will suffice. See note 4 supra (Part I). As is inevitable with any statutory language, there is other possible flexibility as well. For example, the provision that compensation be made "as required by international law," although qualified by rcference to "speedy compensation," "convertible foreign exchange," and "equivalent to the full value" leaves a bit of elbow room.

On the other hand there are limits to "interpretation" and executive indulgence in it. $C f$. remarks of Senator Miller about executive interpretation of FAA $\S 620(e)(1)$ ("some interpreters of what we do in Congress like to play games with words . ...), I09 CONG. REc. 21764 (1963); and such interpretation may lead, and has indeed led, to further tightening of legislation. Thus, the suggestion that expropriations of "property" did not include repudiation of contracts (by Argentina in I963) led to the later addition of FAA $\S 620(\mathrm{e})(1)(B)$. STEINER \& VAGTS 374.

In this connection it should be noted that the existence of waiver authority can also be deceptive. The President has rarely exercised his waiver authorities. An exception to this general statement has been waiver of some restrictions on military assistance, e.g., FAA $\S 505$-but the prospect of the relevant congressional committee support has made this possible. When congressional support for waivers is not present, the result of the exercise of waiver authority can be the elimination of it. This happened with respect to the so-called "country limitations" (although FAA \& 614(a) remains technically available). See note 373 supra.

A final problem with some waivers is that their public exercise may be embarrassing, because of the determinations that they entail. Thus, FAA \& $620(v)$ requires the President to find that the purchase of sophisticated weapons by the recipient government "is important to the national security of the United States." Cf. FAA $\S 504$ (a) (similar finding concerning military assistance for such weapons). The publication of such a determination in some foreign countries would certainly embarrass their governments. Possibly such determination can be classified; however, 620(v) in fact requires a report to the Congress; $c f$. problems of exccutive secrecy, notes 324-30 supra and accompanying text.

376. See note 149-91 supra and accompanying text. 
and is usually resolved without affecting private rights.' 377 Consequently, it may be difficult to find a justiciable "case or controversy," or a party with suitable "standing" to raise the relevant issues before a court. ${ }^{378}$ As stated by Abram Chayes: "Sometimes it is . . . difficult to formulate a satisfying claim on behalf of a private party against which government action can be tested. New claims are struggling to emerge all the time . . . but it is by no means clear how they gain acceptance as a proper basis for court consideration of government action." 379

The "political question" doctrine also helps to account for the lack of judicial definition. According to Professor Corwin, it

explains the lack which we have frequently noted of definite legal criteria for determining the scope of the President's powers in the field of foreign relations and for deciding those contests for power in this field which have frequently occurred between the President and Congress or the President and the Senate. Such criteria lack because the courts have never had occasion to develop them . . . because of this concept. ${ }^{350}$

Many explanations have been given for application of the doctrine to particular cases.381 Among the principal ones would appear to be "lack of judicially discoverable and manageable standards for resolving" "382 the issues involved; inability to formulate a suitable remedy; ${ }^{383}$ and generally, and possibly most crucially, whether the matter is too "hot" politically for the court to handle. ${ }^{384}$ A nother explanation may be relevant to foreign affairs: the feeling that courts, as instruments of the internal order, may not be especially equipped to deal with the external one. ${ }^{385}$ It is no doubt this which explains the general deference of the courts to the "political departments" -both

377. See Hearings, Separation of Powers 142. See also Marbury v. Madison, 5 U.S. (1 Cranch) 137, 165-66 (1803).

378. The latter appears to be an aspect of the former. See Flast v. Cohen, 392 U.S 83, 98

(1968). Standing requirements may be undergoing some relaxation. Id.

379. Chayes 1406.

380. CORWIN-FOREIGN RELATIONS 166-67.

381. See Baker v. Carr, 369 U.S. 186 (1962). See, e.g., Scharpf, Judicial Revicw and the Political Question: A Functional Analysis. 75 YALE L.J. 517 (1966) [hereinafter cited as Scharpf]; $c f$. Chayes, supra note 318; Nathanson, The Supreme Court as a Unit of the National Government: Herein of Separation of Powers and Political Questions, 6 J. PUB. L. 331 (1957).

382. Baker v. Carr, 369 U.S. 186, 217 (1962) To this extent the doctrine appears to be an aspect of the problem of justiciability. See Flast v. Cohen, 292 U.S. 83,95 (1968).

383. 369 U.S. at 198.

384. Scharpf.

385. See generally R. Falk, The Role of Domestic Courts in the International LEGAL ORDER (1964). 
executive and legislative-in foreign affairs. ${ }^{386}$ However, a careful study of these areas of deference, including treaty interpretation, sovereign immunity, and the act of state doctrine, ${ }^{387}$ shows that it has usually pertained to the questioned correctness of an exercise of discretion, not to the constitutional limits on the area in which the discretion can be exercised. ${ }^{388}$

Questions of the separation of powers are not, it is submitted, "political" questions-even in the area of foreign affairs. ${ }^{389}$ The Supreme Court noted in the landmark case of Baker v. Carr: "Deciding whether a matter has in any measure been committed by the Constitution to another branch of government, or whether the action of that branch exceeds whatever authority has been committed . . . is a responsibility of this Court as ultimate interpreter of the Constitution." 390 On the other hand, Professor Chayes sounds a warning note. He suggests, and quite rightly, that in point of fact most accommodations between the executive and Congress do not take place in the courts, but rather in the political arena. He further suggests that it is wrong to think of the executive and the Congress, although certainly subject to the Constitution and its standards, as "subjects" of law and the courts in the same sense as individuals. ${ }^{391}$ Their practical power is such, relative to the courts, that their status is more akin to nation-states in the international order whose subjection to law is certainly problematic. ${ }^{392}$ While this is so, it perhaps proves too much, for it applies equally to domestic affairs where the courts have in fact taken on such tasks. Consider, for example, Myers $v$. United States, ${ }^{393}$ Youngstown Sheet \& Tube Co. v. Sawyer, ${ }^{394}$ United States v. Klein, ${ }^{395}$ Powell v. McCormack, ${ }^{396}$ or even cases involving the

386. Harisiades v. Shaughnessy, 342 U.S. 580 (1952); Chicago \& S. Air Lines v. Waterman S.S. Corp., 333 U.S. 103, 111 (1948); Oetjen v. Central Leather Co., 246 U.S 297 (1918).

387. Foreign affairs areas to which the political question doctrine has been applied are discussed in Baker v. Carr, 369 U.S. 186, $211-13$ (1962).

388. Cf. Chicago \& S. A ir Lines v. Waterman S.S. Corp., 333 U.S. 103 (1948).

389. "[l]t is error to suppose that every case or controversy which touches foreign relations lies beyond judicial cognizance." 369 U.S. 186, 211 (1962).

390. Id.; Powell v. McCormack, 395 U.S. 486 (1969).

391. Chayes, supra note 318, at 1400; cf. Christie, The Model of Principles, 1968 DuKE L.J. 649, 652 n.13; Hughes, Civil Disobedience and the Political Question Doctrine, 43 N.Y.U.L. REV. 1 (1968).

392. See generally Symposium, Comments on Powell v. McCormack, 17 U.C.L.A. 1 (1969).

393. 272 U.S. 52 (1926).

394. 343 U.S. 579 (1952).

395. 13 Wall. 128 (1871).

396. 395 U.S. 486 (1969). 
question of the permitted extent of Congressional delegation of authority ${ }^{397}$

What are the chances of the foreign aid restriction questions coming to the courts? De Toqueville once observed that "[s]carcely any political question arises in the United States that is not resolved, sooner or later, into a judicial question." 328 Cases and controversies-with parties of standing-can be contrived. The following possibilities suggest themselves:

(1) Congress might, by statute, direct a particular company to undertake a foreign enterprise within the "core area" and direct the President to make payment to it. ${ }^{399}$

(2) The President might direct an executive official to disburse funds in violation of a statute deemed by the President to be an unconstitutional invasion of the core area, resulting in a violation of such official's bond under 31 U.S.C. $\S 82 \mathrm{c}$ which the Comptroller General would feel obligated to challenge. ${ }^{400}$ Presumably, however, the Attorney General, who normally represents the Comptroller General in prosecuting such violations, would not do so in this case. And, it is difficult to conceive the Comptroller General retaining its own counsel to initiate such prosecution. ${ }^{401}$

(3) The government might make a loan to a country in violation of a statute and proceed to sell the notes to an American financial institution, a shareholder of which might then challenge the propriety of the purchase. ${ }^{402}$ In fact, A1D has rarely, if ever, taken notes on its loans, and it is unlikely in the extreme that any financial institution would buy them if it did and sought to sell them, especially if received on a loan in violation of a statute.

(4) A foreign public or private borrower, disbursements under

397. E.g., United States v. Curtiss-Wright Export Corp., 299 U.S. 304 (1936).

398. A. DeToqueville, Democracy in America 280 (1945). Of course it may take time. For example, it took the Supreme Court 137 years to address certain questions concerning the removal power, first raised in the "great debate" of 1789, in Myers v. United States, 272 U.S. 52 (1926).

399. Cf. Perkins v. Lukens Steel Co., 310 U.S. 113 (1940); Kendall v. United States ex rel. Stokes, 37 U.S. (12 Pet.) 534 (1838).

400. Cf. letter from Deputy Attorney General Katzenbach to Director of the Budget Gordon, Dec. 18, 1963, with respect to "committee veto" provision in H.R.9140, the 1964 Public Works Appropriation (copy of letter in author's possession).

401. Cf. special counsel of Congress in United States v. Lovett, 328 U.S. 303 (1946). See also Wilentz v. Hendrickson, 133 N.J. Eq. 447, 33 A.2d 366 (Ct. Ch. 1943), aff d, 135 N.J. Eq. 244, 38 A.2d 199 (1944), where the Attorney General of New Jersey sued to enjoin an official from enforcing an unconstitutional statute; Alaska v. American Can Co., 358 U.S. 224 (1959).

402. Cf. Smith v. Title and Trust Co., 255 U.S. 180 (1921). 
whose loan were terminated pursuant to a statutory section, might sue the United States Government. ${ }^{403}$

(5) Conceivably, the Attorney General might seek a declaratory judgment as to the constitutionality of a section and might be deemed to have standing in the absence of a private party to raise the issue.

Cases (1)-(4) are most likely to involve restrictions found in classes a-g discussed above which, on simple analogy to the balance struck for the traditional core area, the court might quite easily find invalid. Case (5) could involve such restrictions or restrictions of classes $h$ and $i$ as well. With respect to the latter, judicial definition has been largely non-existent. ${ }^{404}$ Here the court would not only have to analogize the substance of the new core area to the old, but determine whether some of the "niceties" discussed constitute improper controls or not, something it has not previously done.

\section{Executive Initiative and Congressional Restraint}

While judicial definition would certainly help, history suggests that the executive and the Congress must themselves make the major contribution to the resolution of the constitutional problem; constitutional standards of separation of powers between executive and legislature are as much, if not more, matters of political history as of judicial precedent. In this respect, political history has not caught up with foreign aid.

To be sure, a congressional-executive resolution may not draw as fine lines as would "principled" and "rationalized" decisions by the judiciary. ${ }^{405}$ On the other hand, the applicable standards would work rather simply, at least in part. That is, there would be no controls of classes $a$ through $g$ over that substantive part of the new core area most analogous to the traditional core area. As for other parts of the new core area and controls in classes $h$ and $i$, some judicial definition, once the executive and the Congress break the ice, might be indicated.

It is thus suggested that the ice will be broken only if Congress is prepared to acknowledge the constitutional limitations upon itself and restrain itself to stay within them. Although there is little, at least in recent history, to suggest Congress would so restrain itself, it does not lie beyond the realm of possibility. In the first instance, greater executive restraint in foreign affairs, especially in those which trouble

403. Wilkins, supra note 308, at 999.

404. See notes 360-75 supra and accompanying text.

405. See generally Christie, supra note 391 . 
Congress, may help matters. Thus, Senator Fulbright has stated, "When the Executive tends to ignore Congressional recommendations, intruding thereby on Congressional prerogative, the result is either a counter-intrusion or the acceptance by the Congress of the loss of its prerogatives." ${ }^{406}$ The restrictions on foreign aid are clearly among the principal "counter-intrusions"' Senator Fulbright has in mind..$^{407}$ Of course, Vietnam is not the first-nor presumably the last-executive initiative to disturb considerable elements in Congress. ${ }^{408}$ Moreover, congressional restrictions on aid antedate Vietnam and are not, by any means, all reactions to executive initiative. Rather, as Senator Fulbright has indicated: "Foreign aid provides the closest thing we have to an annual occasion for a general review of American foreign policy. It provides the opportunity for airing grievances, some having to do with economic development, most of them not . . . " ${ }^{409}$ A review of foreign aid legislation from its inception would give one a fairly good idea of congressional foreign affairs worries, although the exact grievances enacted into legislation depend to some extent on the accidental coincidence of events and the legislative cycle.40

Continued improvement in the machinery and practice of consultation and collaboration between the executive and Congress, short of the statutory controls assailed in this article, especially with respect to the development of consensus on major foreign policy directions, ${ }^{411}$ would help the process of reconciliation. Of course, new and additional modalities of coordination of the executive and the Congress are already developing. The executive has since World War II increasingly consulted the Senate and House foreign affairs leadership, in the Senate Foreign Relations Committee and elsewhere, on all foreign affairs matters-not just treaties. ${ }^{412}$ Whether such consultation should and can extend beyond the leadership is questionable. ${ }^{413}$. The executive has acknowledged the importance of

406. Hearings, Separation of Powers 44.

407. Id.

408. Our adhesion and commitment of troops to NATO and our action in Korea provoked considerable congressional reactions. Mathews 363-65.

409. Hearings, Separation of Powers 43.

410. Thus FAA $\S 620(0)$, note 334-35 supra and accompanying text (with respect to mob action), was initially introduced as a "sense of Congress" provision in FAA $\S 102$ by the Foreign Assistance Act of 1965 after the sacking of the USIA library in Cairo.

411. See note 328 supra.

412. See generally D. Acheson, Present at the Creation (1969); Mathews 349.

413. Cf. 1967 Hearings 151. 
such consultations and devices as the Tonkin Gulf resolution. ${ }^{414} \mathrm{On}$ the other hand, Senator Fulbright notes that:

"Consultations" which are really only briefings, and resolutions like the Tonkin Gulf resolution, represent no more than a ceremonial role for the Congress. Their purpose is not to elicit the views of Congress but to avoid controversy of the kind President Truman experienced over the Korean War. They are devices, therefore, not of congressional consultation but of executive convenience. Insofar as the Congress accepts them as a substitute for real participation, it is an accomplice to a process of illicit constitutional revision. ${ }^{\text {115 }}$

Senator Fulbright has proposed a number of innovations, one of which is public hearings of thc Senate Foreign Relations Committee, with expert witnesses giving testimony, to serve as a "forum" to assert values and objectives and to shape policy. ${ }^{416} \mathrm{He}$ has further proposed congressional resolutions calling for congressional concurrence by treaty, legislation, or other legislative expression in certain national commitments. ${ }^{417}$

The above proposals do not immediately concern the core. ${ }^{418} \mathrm{ln}$ fact, as indicated in Part $I$, Congress retains many devices, ${ }^{419}$ other than the forbidden statutory controls, to check the executive's exercise of its exclusive powers over the core area, including (1) various indirect means of persuasion or compulsion ${ }^{40}$ and other private communications; ${ }^{421}$ (2) clearances with key legislators ${ }^{422}$ and understandings which may or may not be binding;423 (3) committee

414. Id. at 75, 129 et seq., 187.

415. Hearings, Separation of Powers 49; 1967 Hearings 242.

416. Hearings, Separation of Powers 52.

417. 1967 Hearings 242. Such new modalities of consultation as emerge should of course leave the core area to the President. Thus Senator Fulbright has acknowledged that the President's decision as Commander-in-Chief vis-a-vis Vietnam, while they may be the subject of advice, are his alone to make. N.Y. Times, March 13, 1968, at 14, col. 2 (city edition).

418. For a description of the traditional core area see notes $149-92$ supra and accompanying text (Part I).

419. See generally Ginnane, The Control of Federal Administrations By Congressional Resolutions and Committees, 66 HARv. L. Rev. 569 (1963); Newman \& Keaton, Congress and the Faithful Execution of Laws-Should Legislators Supervise Administrators? 41 CALif. L. REv. 568 (1953).

420. Whelan \& Phillips, Government Contracts: Emphasis on Government, 29 LaW \& Contemp. Prob. 315, 324 (1964).

421. Fenno, supra note 68, at 130 (Part 1).

422. Newman \& Keaton, supra note 247, at 566 n.3 (President's Eisenhower's instruction to his cabinet to clear all major policy matters with Senator $\mathrm{Taft}$ ).

423. Cf. 1967 Hearings 108 (Katzenbach: "Indeed, in some decisions, President Johnson has come to the Congress where the power was already given him and authorized him.

For example, on the AID program to India, where the amount was so large he felt that the Congress should have an opportunity to express itself on that point"). Id. 
reports; $; 4$ (4) reports which the executive can be required to make; ${ }^{425}$ (5) annual hearings with respect to legislation and appropriations; ${ }^{428}$ (6) investigations which, although in theory subject to a limitation that they be for a "legislative purpose," can be a real source of pressure on the executive; ${ }^{227}$ (7) annual appropriations, short term authorizations, and fiscal year funds; ${ }^{128}(8)$ certain general legislative provisions, even if specific restrictions are prohibited; ${ }^{42}$ (9) sense of Congress provisions, resolutions and similar "advice"; $; 30(10)$ the force of public opinion; ${ }^{\mathbf{4 1}}$ the consensus building process ${ }^{\mathbf{3 2}}$ and the prospect of elections;, (11) the President's "conscience" "134 and "his sense of self-restraint" - which are possibly the most significant controls;",35 and (12) ultimately, the "scarecrow"

Congressional restraint is called for because of the constitutional precedents, and for the constitutional reasons given, Congress should be persuaded to abandon forbidden statutory controls over the core area. In restraining itself, the Congress will want to refrain from waivable, as well as unwaivable, restrictions, primarily because of the inhibiting effect of the former. To be sure, the executive will have to "push" to encourage and maintain congressional self-restraint generally and to indicate the exact lines of such self-restraint. Indeed it is arguable that the President, because of

424. C. Zinn, Role of Congress, supra note 175, at 18. It has been pointed out that committee reports are not subject to revision by the full Congress, Hearings, Separation of Powers 193 (Professor Maas: "Appropriations Committee reports are filled with words of guidance, advice, requests, warning and direction, so that a departmental budget officer may be as much or more concerned with the committee report than he is with the appropriations statute. Yet the report is extra-legal. Neither House of Congress votes on it. The President neither signs nor vetoes it").

425. C. Zinn, Extent of Control of Executive by Congress, supra note 175, at 19. But cf. notes 225-39 supra and aecompanying text (executive secrecy).

426. 1967 Hearings 75.

427. Gellhorn \& Byse 176.

428. This can of course be a great control. Fenno, supra note 151.

429. Supra notes $189-90$ (Part I).

430. 1967 Hearings 239.

431. Steelman \& Kreager, supra note 233, at 691.

432. Supra note 284.

433. Marbury v. Madison, 5 U.S. (1 Cranch) 137, 165 (1803). See 1967 Hearings 121. The decision by Congress to withhold funds, if the swing in amount is large enougb, is probably more subject, although marginally so, to political repercussions than any restriction on the President's discretion. Cf. 41 OP. AtT'Y GEN. 32 (1949).

434. Marbury v. Madison, 5 U.S. (1 Cranch) 137, 165 (1803).

435. McDougal \& Lans 615.

436. CoRWIN-PRESIDENT 292.

437. 1967 Hearings. See Part I, pages 327-28. 
his Constitutional oath to "protect and defend the Constitution" 438 against, among other things, congressional encroachment on his powers, ${ }^{130}$ is duty bound to do so. The device that the President might use-given an indication of congressional willingness to restrain itself-is at hand in the presidential signing message. As we have seen; the President has increasingly indicated in signing messages that he will ignore certain provisions in legislation or treat them in such a way as to avoid constitutional problems. ${ }^{40}$ To be sure, the President should use the device sparingly: But, he must have the will to use it. The practical difficulties can not be minimized. The executive's annual requests for appropriations have been regularly cut by the Congress, and congressional resentment of executive efforts to disregard the restrictions could lead to further cuts. That is why congressional self-restraint is the key to the proper accommodation of congressional and executive interests. Congressional conviction that executive initiatives with respect to foreign aid will not lead to other "Vietnams" is vital. But finally, there must be executive and congressional realization that although foreign aid and economic development are not now in the forefront of national priorities, they

438. U.S. CoNST. art. II, $\$ 1$, cl. 8 .

439. Presidents have construed their oath as placing them under a duty to resist congressional encroachment on their powers and have done so by various devices including vetoes, signing messages declaring portions of statutes to be unconstitutional, and protests-successful and otherwise - against pending legislation. Warren, Presidential Declarations of Independence, 10 B.U.L. Rev. 1, 3 (1930). President Eisenhower, at the time of the Bricker Amendment controversy, said, "As President 1 have taken an oath to defend the Constitution. I therefore oppose any change which will impair the President's traditional authority to conduct foreign affairs." Sutherland, The Bricker Amendment, Executive Agreements, and Imported Potatoes, 67 HARv. L. Rev. 281, 283 (1953). President Buchanan stated that the people have "rights and prerogatives" in the President's execution of his office which each President is under a duty to see "shall never be violated in his person" and shall "pass on to his successors unimpaired by the adoption of a dangerous precedent." Warren, supra, at 35.

440. See, e.g., notes 316-18 supra (P.L. 480 committee vetoes) and 315 (Spanish loan). Cf. N.Y. Times, Oct. 10, 1968, \& 4, at 13, col. 8 (city edition) (report that President would ignore certain sections of crime bill as unconstitutional). See also President Tyler's early resort to a similar device. Warren, supra note 439 , at 13 . To be sure this device resembles an "item veto" which the President does not have. 80; Note, The Legislative Rider and the Veto Power, 26 GEo. L.J. 954 (1938). The President may of course use his regular veto power to resist what he conceives to be unconstitutional encroachments. CORWIN-PRESIDENT 80.

The signing message device, if valid, might raise questions of separability. $C f$. Stern, Separability and Separability Clauses in the Supreme Court, 51 HARv. L. REv. 76 (1937). FAA $\$ 646$ provides that the validity of the remainder of the FAA will not be affected if any provision "shall be held invalid." 
remain so in global priorities and will one day reassert themselves in our own thinking. When that time comes, as it will, the executive must have restored to itself the freedom it will need to do the job properly. This will take congressional and executive self control. ${ }^{42}$

441. James Madison once wrote, "In framing a government which is to be administered by men over men, the great difficulty lies in this: you must first get the government to control the governed; and in the next place oblige it to control itself." THE FEDERALIST No. 51 , at 323 (H. Lodge ed. 1888) (J. Madison). "Our scheme of society is more dependent than any other form of government on knowledge and wisdom and self-discipline for the achievement of its aims." Youngstown Sheet \& Tube Co. v. Sawyer, 343 U.S. 579, 593 (1952) (Frankfurter, J., concurring). 